\title{
Studies on the Chloroplasts of Desmids. III.
}

\section{The Chloroplasts of Cosmarium.}

\author{
BY \\ NELLIE CARTER, D.SC. \\ With Plates X-XIII and two Figures in the Text.
}

ERTAIN types of chloroplast structure have long been known to occur in the genus Cosmarium. A very common form, especially amongst the smaller species of the genus, in which there is a simple four-lobed chloroplast with a single central pyrenoid, was described and figured by Nägeli (1849) and de Bary (1858), as well as certain later investigators.

In a second type, first figured by Nägeli (1849) for C. margaritiferum and C. Botrytis, and later by de Bary (1858), Delponte (1873), and others, there are two chloroplasts in each semi-cell, each with a central pyrenoid and several radiating plates.

Lastly, several species of the genus were known to possess parietal chloroplasts. De Bary (1858) and Delponte (1873) figured such parietal chloroplasts in C. turgidum, whilst the latter investigator also indicated a similar condition in C. ovale. Klebs (1879) and Gay (1884) also figured parietal chloroplasts in $C$. de Baryi and C. cucumis respectively, and Lütkemüller (1893) investigated the more detailed structure of some of these parietal chloroplasts.

Chloroplasts of all these types were figured in many species by W. and G. S. West (1904-11), and in this work it is also indicated that other types of structure than these three probably occur in the genus, but without carefully stained material it is impossible in most cases to determine the structure of the chloroplasts, and in the majority of species definite information is entirely wanting.

It has long been known that the majority of the genus have axile chloroplasts, and several investigators have considered the comparatively few species known to possess parietal chloroplasts to be worthy of a special genus. Thus Lundell (1871) instituted the sub-genus Pleurotaeniopsis to contain all such species, and Lagerheim (1887) raised this to the rank of a genus. Again, Gay (1884) created a new genus Cosmaridium to include

[Annals of Botany, Vol. XXXIV. No. CXXXIV. April, 1920.] 
C. cucumis, a species characterized by parietal chloroplasts. Such classifi- cations based on the structure of the chloroplast were very unwise, particularly since at that time the form of the chloroplasts was known only in comparatively few species, and these had usually only been investigated in the living condition. Thus it is not surprising that several species were wrongly placed. C. Ralfsii and C.elegantissimum, two species believed by Lundell to possess parietal choroplasts and placed by him in Pleurotaeniopsis, have since been found to be provided with axile ones, whilst in two other species hitherto believed to have axile chloroplasts, C. Brebissonii and C. controversum, the chloroplasts are now known to be parietal. So that in any case such a division was quite unjustifiable whilst information was so scanty concerning the chloroplasts of the genus.

Again, it has been pointed out by W. and G. S. West (1904-11), that this classification according to the form of the chloroplasts is an unnatural one, resulting in the separation of closely related species. Thus it sometimes happens that chloroplasts of very different forms are found in quite closely related species, e.g. C. cucumis and C. subcucumis, C. binum, and C. speciosum.

Parietal chloroplasts seem to have been developed in general in the largest species of the genus, although there are a number of very large species which still retain the axile form. But in these there is a marked tendency to the formation of parietal films of chloroplast. These parietal films were observed in several species (Figs. $2 \mathrm{I}, 37,56,69$, and $7 \mathrm{I}$ ), but they are frequently very delicate and are difficult to distinguish except after staining. The extent of the parietal layer depends on the profuseness of the chlorophyll. If the chloroplast is fairly massive, then the film will be fairly continuous, whilst if it is scanty there may be just a slight extension of the ridges over the surface of the wall.

Thus it appears that in these large cells the chloroplasts tend to concentrate as much as possible towards the periphery, where they can be of greater help in the process of photosynthesis; but, whilst in some species the chloroplasts have become entirely parietal, others are content to retain the axile form, but mantle the surface of the cell-wall with photosynthetic material, so as to make the best use of their substance. The distinction between parietal and axile chloroplasts is therefore not so clear as was formerly believed to be the case, since in certain axile chloroplasts there may be parietal layers as well. That a sharp line cannot be drawn between parietal and axile chloroplasts is also illustrated by $C$. Brebissonii. Here the chloroplasts are very variable, and whilst in some individuals they may be distinctly parietal, in others they penetrate into all parts of the cell; cf. Figs. 77-8r.

Lütkemuiller (1893) drew attention to a peculiar character of the parietal chloroplasts of some species of Cosmarium - that the parietal bands 
or plates containing the pyrenoids are in some cases covered with tiny outgrowths of chloroplost stretching towards the cell-wall. He found that in C.tessellatum these outgrowths were arranged in a definite relation to the warts on the external surface of the wall, each outgrowth being exactly under a wart, but he observed that such outgrowths were also present in species which are not provided with such nodules, e g. C. turgidum, C. de Baryi. Luitkemuiller was unable to give any explanation for the occurrence of these outgrowths, and raises the question whether they are characteristic of Lagerheim's genus Pleurotaeniopsis, observing that he had not been able to ascertain the presence of such outgrowths on the parietal chloroplasts of any species of Xanthidium, Pleurotaenium, or Spirotaenia he had examined. During the present investigation similar outgrowths have been observed in species of Pleurotaenium, Euastrum, Xanthidium, and also in other species of Cosmarium, so that this character cannot be considered unique to Pleurotaeniopsis. It is possible that this formation of outgrowths is a convenient method of increasing the surface of photosynthetic material exposed to the exterior. It only occurs in chloroplasts which are fairly massive. Where only a delicate film of chloroplast is present such outgrowths never occur, because the whole of the chloroplast is sufficiently exposed to the light. But if there is a fairly thick layer lining the cell-wall, then part of it is projected outwards in the form of outgrowths. Obviously this arrangement is much better than having a simple thick layer of chloroplast. The relation in some species of the outgrowths to the warts on the cell-wall is a rather more difficult problem, since many species having no warts are provided with outgrowths, and in at least one species having warts, Cosmarium Brebissonii, the outgrowths are not arranged in any definite relation to these.

With regard to the pyrenoids, there has been some misunderstanding concerning the number of these bodies occurring in the genus. It was formerly believed that, excluding those species having parietal chloroplasts, all other species of Cosmarium were provided either with one or two pyrenoids in each semi-cell. The first investigator to show that this rule was not without exception was Lütkemüller (1893), who reported the presence of unusually large numbers of pyrenoids in C. pyramidatum and a few other species.

Later, Ducellier (1917) made further observations supporting those of Luitkemüller. He also attempted to show that there is some relation between the actual size of the cell and the number of pyrenoids contained in it, examining several species of the genus in order to prove that individuals containing an unusually large number of pyrenoids are often larger in size than individuals of the same species having fewer pyrenoids.

Although it may be true, in general, that large-celled species often have more pyrenoids than the smaller ones, it can scarcely be true in the 
consideration of specimens of any one particular species, because of the varying factors in each individual cell. Thus there is considerable variation in the amount of green material contained in different individuals of the same species, irrespective of size, and, again, there is also great variation in the size of the pyrenoids themselves; cf. Figs. 78 and 80. Besides this, in all species of Cosmarium which have hitherto been regarded as having one or two pyrenoids in each semi-cell, there is, as in other genera, the possibility of the division of one or both the original pyrenoids to form a group which occupies the same relative position in the cell (Figs. 56, 57, and 69). Thus there is normally the possibility of considerable variation in the number of pyrenoids. The factors which influence the division of the original pyrenoids are very obscure, and cannot simply be external, since the pyrenoids in one part of the cell may divide to form such groups, whilst in other parts of the cell they do not (Figs. $5^{6}$ and 69). For this reason it is quite impossible to draw any relationship between the number of pyrenoids and the size of the cell.

In the living condition the compact groups of pyrenoids resulting from the division of the original ones cannot be distinguished from single pyrenoids, and so this variability of number has not generally been observed.

The position of the pyrenoids in the axile chloroplasts of Cosmarium is dependent on the shape of the chloroplast, and so the points at which they may occur are usually fixed. Thus, although the actual number of pyrenoids is not constant, the number of pyrenoid groups is, since, as a rule, the shape of the axile chloroplast is particularly constant.

Thus the old idea that all species of Cosmarium having axile chloroplasts were provided either with one or two pyrenoids, although not strictly true, was not without foundation, for there are many species which, whilst not having invariably either one or two pyrenoids in each semi-cell, yet usually have either one or two groups, each group consisting of one to four pyrenoids, and appearing to have been formed from the division of an original pyrenoid (Figs. I-23, 28-32, 37-57, and 62-72). The reason that so many species have either one or two points of pyrenoid formation is that two corresponding types of chloroplast structure happen to be very common in the genus. Occasionally there are more than two points of pyrenoid formation in a semi-cell. Thus in C.pseudoconnatum there are four (Figs. 35 and $3^{6}$ ). It is only very rarely that the pyrenoids do not occur in definite positions in the axile chloroplasts of Cosmarium, the only examples encountered during this work being $C$. Ralfsii and C.ornatum (Figs. 33, 34, and 58-6I). In the former species particularly the pyrenoids are both very numerous and scattered. The opposite is the case with those species having parietal chloroplasts, however, for here it is the rule for the pyrenoids to be indefinite in number and scattered (Figs. 73-88). 
The species of Cosmarium examined during this investigation included C. subtumidum, Nordst., C. punctulatum, Bréb., C. contractum, Kirchn., C. crenatum, Ralfs, C. depressum, Lund., C. caelatum, Ralfs, C. speciosum, Lund., C. cucurbita, Bréb., C. curtum, (Bréb.) Ralfs, C. elegantissimum, Lund., C. diplosporum, (Lund.) Lütkem., C. pyramidatum, Bréb., C.pseudopyramidatum, Lund., C. achondroides, West, C. pseudoconnatum, Nordst., C. ornatum, Ralfs, C. Ralfsii, Bréb., C. praemorsum, Brẹ́b., C. formosulum, Hoff, C. binum, Nordst., C. margaritiferum, Menegh., C. Turpinii, Brẹ́b., C. pachydermum, Lund., C. ochthodes, Nordst., C. Botrytis, Menegh., C. tetraophthalmum, Bréb., C. amoenum, Bréb., C. subcucumis, Schmidle, $C$. reniforme, (Ralfs) Arch., C. biretum, Bréb., C. Brebissonii, Menegh., C. cucumis, Corda, C. controversum. West, C.ovale, Ralfs, and C. Askenasyi, Schmidle. Of these thirty-five species the first thirty have axile chloroplasts, of which twelve have one point of pyrenoid formation per semi-cell, thirteen, two points of pyrenoid formation, whilst in five the chloroplast has an unusual structure. The five last-mentioned species have parietal chloroplasts.

All the species examined having axile chloroplasts have either one or two chloroplasts in each semi-cell. When only one is present it occupies a central position, whilst when there are two they are placed transversely, side by side in the semi-cell. The pyrenoids are usually, though not invariably, embedded in the axis of the chloroplast, often typically one in each, which may give rise to a group of two to four. In a few species more pyrenoids than one are invariably present in each chloroplast, in which case the latter is always unusual in shape. With the exception of $C$. Ralfsii the points at which pyrenoids may occur are nearly always definite and fixed.

The axis of the chloroplast containing the pyrenoids is always provided with a variable number of strands or more definite plates which radiate towards the cell-wall. Their peripheral edges sometimes spread out over the latter, forming more or less extensive parietal layers or films of chloroplast. In a few species these parietal films are the seat of numbers of small proteid granules or naked pyrenoids (Figs. $37-49,56$, and 70 ). The latter have no relations with the large pyrenoids in the axis of the chloroplast, and are probably formed de novo when the conditions are favourable.

\section{C. subtumidum, C. punctulatum, C. contractum, C. crenatum, and $C$. depressum.}

The simplest chloroplasts of the genus were found in these five species, and here, corresponding to the shape of the semi-cell, there is a rather massive axis in the centre, containing usually one pyrenoid (Figs. 3-5, 7, 9, I 8-20, and 32). If this original pyrenoid divides, the products of its division may sometimes separate to some little distance, because of the comparatively great width of the axis (Fig. 2), but: although they may not 
actually be crowded together, they are nearly always confined to the limits of the axis itself. The axis of the chloroplast gives off four massive lobes which sometimes fork towards the periphery, ending with toothed or smooth edges near the cell-wali (Figs. 9, 20, and 32). In other cases the plates are bent so as to embrace a considerable part of the cell-wall in a parietal manner (Figs. 18 and 20). Very often more than four plates are to be seen, the extra ones being smaller and inserted between the main lobes, stretching towards the front faces of the cell (Figs. 3, 4, 7, 18, and 19). The thickness of the plates varies considerably; in some individuals only sharply defined fringed edges lie against the cell-wall (Figs. I, 2, 6, I6, and I7), whilst in others the whole chloroplast may be much more massive, and the cell-wall may be almost entirely covered by the broad edges of the ridges (Figs. 8 and $3 \mathrm{I}$ ). Such differences in the character of the chloroplasts are doubtless to be correlated with the amount of stroma starch contained in them.

\section{C. caelatum and $C$. speciosum.}

In these two species the chloroplasts only differ from those of the above five species in the rather larger number and more simple form of the plates radiating from the axis. The first-mentioned species has about eight such plates (Fig. II), whilst in C. speciosum there are about ten (Fig. 30). In both cases all the ridges are quite similar to each other, except that those running towards the lateral edges of the semi-cell are naturally larger than those which go towards the front faces. The plates or ridges rarely branch, and end simply on reaching the cell-wall, no attempt at the formation of parietal films of chloroplast being observed (Figs. I0, 28, and 29).

\section{C. cucurbita and C. curtum.}

In those species examined having cylindrical cells the chloroplasts are not very different from those already described. C. cucurbita has in each semi-cell a central axis containing usually one pyrenoid, and from this radiate about eight very distinct thin plates, which end near the cell-wall with lobed or fringed edges (Figs. I4 and ${ }^{1} 5$ ). C. curtum has a chloroplast which is quite similar to that of C. cucurbita. Its simple axis is usually provided with a single pyrenoid, and there are about eleven plates radiating towards the periphery, ending with sharp edges against the interior of the wall (Text-fig. I, A and B). Occasionally the ridges were observed to be twisted slightly in a spiral. In these two species, as in all the others dealt with so far, the axis does not always extend right to the apex of the semicell, and where this is the case the radiating plates extend beyond it until they reach the extremity of the cell, enclosing a chlorophyll-free space between them ; cf. Figs. I, I 4, I6, I 7, 28, and 29. This is very pronounced in young semi-cells. 


\section{C. elegantissimum.}

This species seems to have a chloroplast which is quite similar in all essential points to that of C. cucurbita, although it was described -by Lundell (1871) as having its chloroplasts in the form of parietal bands, and was placed by him in the sub-genus Pleurotaeniopsis, together with other species having parietal chloroplasts. Only one specimen was encountered during this investigation, and this had a central pyrenoid in each semi-cell, the chloroplast forming an irregularly shaped mass round it, with several short outgrowths radiating towards the periphery in various directions

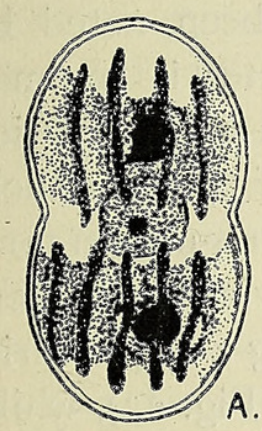

B.
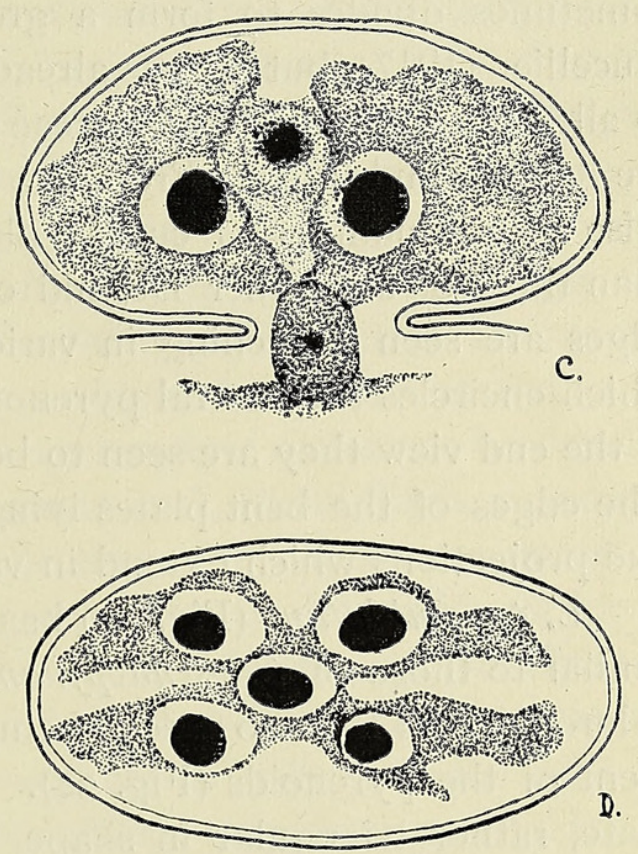

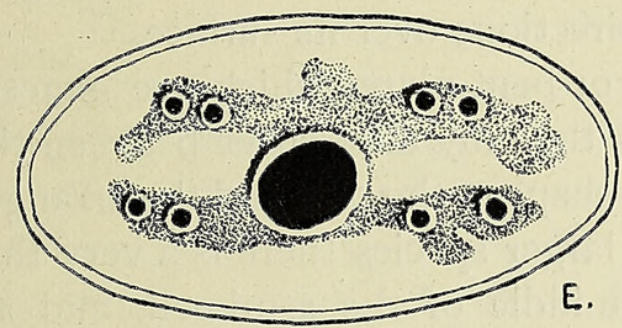

TEXT-FIG. 1. A and B, Cosmarium curtum, (Bréb.) Ralfs: A, front view; B, end view. C-E, C. achondroides, West: C, front view of semi-cell; D, typical optical transverse s€ction; $\mathrm{E}$, optical transverse section of another individual unusual in its pyrenoids. All $\times 8 \mathrm{r}$.

(Figs. 12 and 13). The chloroplasts were undoubtedly axile, and it is possible that in individuals with better developed chromatophores more definite plates like those of Cosmarium cucurbita might be visible. Possibly Lundell mistook the edges of such plates lying against the cell-wall for parietal bands.

\section{C. diplosporum.}

In this species the chloroplasts are rather different from those of any of the other species examined having cylindrical cells, being much more elaborate in their structure. There is a large pyrenoid in each semi-cell, embedded in an axile mass of chloroplast. Instead of a limited number of definite plates, numerous thin string-like strands radiate in all directions from the central mass towards the periphery (Fig. 2I, lower semi-cell). On reaching the cell-wall the end of each ray becomes flattened and extends in 
a parietal manner over its surface, forming an irregularly lobed mass. The whole cell-wall is mantled by these irregularly shaped parietal masses, which form a rough kind of discontinuous network (Fig. 2I, upper semi-cell).

\section{C.pyramidatum and C.pseudopyramidatum.}

The chloroplasts of these two species greatly resemble each other, that of the smaller species, C. psendopyramidatum, being the simpler. In the latter species there is a massive axis occupying the centre of the semi-cell, and containing typically one pyrenoid, although sometimes two or more may be present (Figs. 22 and 23 ). The fact that the central pyrenoid sometimes divides to form a group in this species has been noted by Ducellier (1917), but, as has already been stated, this character is common to all species of the Desmidiaceae in which the points of pyrenoid formation are definite and fixed. From the lateral and apical edges of the axis there arise a large number of curved plates which are far more irregular in form than those of any other Desmid examined. In the front view their bent edges are seen stretching in various directions, but forming a single series which encircles the central pyrenoid or group of pyrenoids (Fig. 22), whilst in the end view they are seen to be arranged in four vertical lines (Fig. 23). The edges of the bent plates lying against the cell-wall are cut into fingerlike projections which extend in various directions over its surface.

C. pyramidatum (Fig. 24) has curved or bent plates which are exactly similar to those of $C$. pseudopyramidatum, the only differences between the chloroplasts of the two species being in the shape of the axis and the arrangement of the pyrenoids (Fig. 24). In the larger species there is a very thin plate, rather triangular in shape, in the middle of the semi-cell, and all round the edges of this the bent plates arise, travelling towards the front faces of the semi-cell (Fig. 24). In the end view, as before, they are seen to be arranged in four main series (Fig. 27). The pyrenoids are very variable in number $(2-14)$, and are arranged in a triangular or horseshoeshaped series in the rather thicker part of the chloroplast where the bent plates arise from the thin axis (Figs. 24 and 25). Usually the pyrenoids all lie in one plane parallel to the front faces of the semi-cell (Fig. 25), but when they are very numerous they seem to separate into two different planes in the bases of the plates themselves (Figs. 26 and 27). Perhaps the most common number of pyrenoids is three, arranged one at each corner of the triangular axile plate (Fig. 24), but, as was noticed by Lütkemüller (1893) and Ducellier (1917), they are very variable. Occasionally only one pyrenoid is present in the central position, as is the case with $C$.pseudopyramidatum, but such cases are rare, the axis in the middle of the cell being usually far too thin for the accommodation of pyrenoids.

Lütkemüller stated that when three or more pyrenoids are present in C. pyramidatum it very often happens that a rounded hole appears in the 
centre of the chloroplast between them. He thought that this rupture was brought about by the travelling towards the periphery of the products of division of an original central pyrenoid, a single pyrenoid being, according to his theory, general at first in all individuals. Whether or not this is so could not be ascertained without the examination of actively dividing material, but considering the behaviour of the chloroplasts of other species during cell-division it seems most likely that, since there are nearly always two pyrenoids at the base of the semi-cell, either these, or possibly in some cases the products of their division, would enter the new semi-cell when celldivision took place, whilst in the case of individuals containing as many as fourteen pyrenoids in a half-cell, the new semi-cell would doubtless be supplied with quite a number of pyrenoids. It is most likely, therefore, that the semi-cells of $C$. pyramidatum often contain originally at least two pyrenoids, in which case the travelling apart of the products of division of an original central one could not explain the formation of the central hole. Although it was observed that the axis of this species is always very delicate, consisting sometimes merely of a delicate reticulum, a cavity such as was described by Lütkemüller was never noticed in such material as was available. It is possible that such a delicate structure could not be detected in the living condition, and that this accounts for Lütkemüller's statement.

Ducellier (1917) reports that one collection of this species examined by him contained quite a large proportion ( 30 per cent.) of individuals having only one pyrenoid in a semi-cell. This may have been a special character developed in that particular locality, for it is quite possible that occasionally in newly-divided specimens the young semi-cell is only provided with one pyrenoid, especially in those forms containing very few pyrenoids. In Ducellier's collection there were never more than two pyrenoids in each semi-cell. It must be remembered that the chloroplast has to push its way from the old semi-cell through the comparatively narrow isthmus into the young-semi-cell after cell-division, and therefore one must not be surprised if distortions sometimes occur. Thus it is quite possible that, following such an abnormal division, the young semi-cell is found to be provided with only one pyrenoid, and repeated division might result in the production of quite a large proportion of such individuals containing only one pyrenoid in a semi-cell, as in Ducellier's collection. Nevertheless it seems true that as a rule there are two or more pyrenoids in the chloroplasts of this species, and that the axis of the chloroplast is usually very delicate, so that the actual centre of the semi-cell is usually destitute of pyrenoids.

\section{C. achondroides.}

This species was originally described and figured by West (1909) as having parietal chloroplasts. A subsequent examination of stained specimens has shown, however, that there is actually one axile chloroplast in each 
semi-cell which is somewhat similar in form to those of $C$.punctulatum, C. depressum, \&c., but differs from these in the arrangement of the pyrenoids. As in the simple chloroplasts of these small species, there is a central axis containing usually one pyrenoid (Text-fig. I, C), but this may occasionally bud off others. From this axis four lobes are given off, which expand to form somewhat massive parietal plates, two of which lie against each front face of the semi-cell (Text-fig. I, C). Commonly there is a large pyrenoid in each of these lobes, equal in size to the central pyrenoid, so that the typical number of pyrenoids is five (Text-fig. 1, D). Those in the lateral lobes of the chloroplast, however, are not so constant as the central one, and occasionally one or more of the lobes may be entirely free from them, whilst in others, if present, the pyrenoids are very reduced in size, and look as if they had been formed de novo. In one semi-cell at least eight such tiny pyrenoids were observed in these lateral lobes (Text-fig. I, E). The most common type, however, had a large pyrenoid in each of the four lobes in addition to the central one, and in every individual examined at least one semi-cell showed this structure.

\section{C. pseudoconnatum.}

The chloroplast of this species is rather different from that of any other species examined. It was originally believed to have parietal chloroplasts, but is mentioned by Lütkemüller (1893) as being the only species included in Pleurotaeniopsis in spite of the fact that it has an axile chloroplast, because it was known to have four pyrenoids in each semi-cell, whilst in Cosmarium proper there were only supposed to be one or two.

The chloroplast of $C$. pseudoconnatum consists of four large wedgeshaped masses arranged symmetrically in each semi-cell, each mass containing typically one pyrenoid, and all four being united in the interior by their thin ends (Fig. 36). Towards the periphery the broad external surface of each mass is grooved to form irregular ridges, whose edges spread out over the cell-wall (Fig. 35).

\section{C. ornatum and C. Ralfsii.}

C. ornatum and $C$. Ralfsii have chloroplasts which show some similarities whilst being different from those of any other species examined. The smaller species, $C$. ornatum, has an axile chloroplast in each semi-cell, consisting of a relatively short broad axis, containing two or three pyrenoids, with about eight plates radiating in various directions towards the periphery (Figs. 33 and 34 ).

The larger species, C. Ralfsii, was for a long time supposed to have parietal chloroplasts, and was placed by Lundell (1871) in his sub-genus Pleurotaeniopsis, together with other species having parietal chloroplasts. Lütkemüller (1910) corrected this mistaken idea by means of a short note and figure. The chloroplast in this species consists of a broad axis occupying 
the middle of the semi-cell, from which a number of branching ridges radiate towards the periphery (Fig. 59). The branching and spreading out of the ridges near the cell-wall result in the formation of broad peripheral masses of chloroplast, which in the living condition doubtless give the impression of parietal bands (Figs. 59 and 6I). The ultimate branches of the ridges end against the cell-wall with smooth or fringed edges. The pyrenoids vary considerably in size and number (6-I4), and are embedded in the thicker parts of the chloroplast, either where the ridges arise from the axile plate, or nearer the periphery, at the points of branching of the ridges themselves (Fig. 6I).

There is a strong tendency in this species towards the hollowing away of the axile plate of the chloroplast in the apical region of the semi-cell, exactly similar to that observed in the thicker-celled species of Micrasterias. ${ }^{1}$ The chlorophyll-free portion is often quite small, but in some individuals it extends right as far as the nucleus, and consequently in such cases there are two chloroplasts in each semi-cell instead of one ; cf. Figs. 59, 6o, and $5^{8}$. The general structure of the chloroplast, and its variations in the median region of the cell, together with the arrangement and variation in number and size of the pyrenoids, are all very suggestive of the thicker-celled species of Micrasterias; in fact it is scarcely possible to distinguish any differences at all between the chloroplasts of this species and $M$. oscitans in transverse section. Moreover, its chloroplast is quite different from that of any of the other species of Cosmarium examined, with the possible exception of the small species $C$. ornatum. There are some similarities between the chloroplasts of the latter species and those of $C$. caelatum and $C$. speciosum; cf. Figs. 33, 10, and 28 ; but in the irregular form of its ridges and scattered pyrenoids it agrees more nearly with $C$. Ralfsii. In $C$. ornatum there are almost invariably two or three pyrenoids, and they never give one the impression that they might have been formed by the division of an original central one. Thus we may assume that in $C$. ornatum, as in C. Ralfsii, there is not merely one point of pyrenoid formation.

The seventeen species dealt with so far possess normally one chloroplast in each semi-cell. The thirteen species which will now be described have two chloroplasts transversely disposed in each semi-cell. In each case the chloroplast has a funnel-shaped axis arising on one side of the nucleus, with which it is in close connexion, and this axis stretches towards the corresponding lateral region of the semi-cell (Fig. 47). It increases in thickness as it passes upwards, and finally ends about half-way between the apex of the semi-cell and the nucleus in a swollen head which contains the pyrenoid or group of pyrenoids (Fig. 47). Two such axes arise, one on each side of the nucleus, and they lie symmetrically, one on each side of the median line.

1 Vide Carter, N.: Studies on the Chloroplasts of Desmids. II. Ann. Bot., vol. xxxiii, I9I9. 
The axis is not usually very large, and if more pyrenoids than one are present they usually cause much distortion (Figs. 57 and 69). From the axis of each chloroplast a number of plates stretch out towards the cell-wall (Figs. $38-49$ ), or in some cases, instead of definite plates, numerous thin strands radiate in all directions towards the cell-wall (Figs. 62-70). In practically every species the edges of the plates or the ends of the strands spread out over the internal surface of the cell-wall to form greater or smaller parietal extensions, but this is doubtless a feature which is subject to considerable individual variation (Figs. $37,50,54,56,67,69$, and $7 \mathrm{I}$ ).

\section{C. formosulum.}

The axis of the chloroplast in this species is provided with about four simple plates which radiate towards the periphery (Text-fig. 2, B), their edges spreading irregularly over the surface of the wall, but only covering a comparatively small area of its surface (Text-fig. 2, A and B).

\section{C. binum.}

This species, which is frequent in the tropics, has chloroplasts which are quite similar to those of $C$. formosulum, but the radiating plates are more massive, and there is some attempt at branching, relatively more of the surface of the cell-wall being covered by their spreading extremities (Figs. 54 and 55). The shape of the cell-wall apparently influences the development of the chloroplast to some extent in this species, for the broad edges of the four lateral plates lying under the marginal crenations of the cell-wall are produced to form four series of short radiating ridges, each ridge corresponding to one of the crenations (Fig. 54). This relation between the cell-wall and chloroplasts recalls the condition described by Lütkemüller (1893) in the parietal chloroplasts of $C$. tessellatum, \&c.

\section{C. margaritiferum.}

The plates radiating from the axis in this species are much more irregular in form than in the two previous species (Fig. 53). In the front view of the cell, their widened extremities are seen running in all directions over the surface of the cell-wall (Fig. 52), and they are frequently seen to branch (Fig. 53).

\section{C. pachydermum.}

The axis of each chloroplast is provided with about five radiating plates (Fig. 72), the edges of which, on reaching the cell-wall, spread out on either side to form finger-like outgrowths, sometimes of considerable length and often branching. These flattened processes are closely adherent to the surface of the wall, and so in the front view the cell is seen to have several irregularly branching strings of parietal lobes of chloroplast (Fig. 71). The 
plates may previously fork before spreading out to form the parietal outgrowths, but probably part of the branching visible in the optical transverse section (Fig. 72) is only apparent, being due to the lateral extension of the outgrowths on both sides of the plate. The actual shape of the outgrowths varies amongst individuals, and the extent of their development depends largely on the size of the chloroplast. In some individuals with slender chloroplasts the edges of the plates form merely a delicate network against the cell-wall, and the beautiful lobing so conspicuous in others is wanting.

\section{Turpinii, C. ochthodes, C. Botrytis, and C. tetraophthalmum.}

These species have chloroplasts which are very similar to each other The axis of each chloroplast gives rise to four to six plates which radiate towards the exterior (Figs. 40, 57, and Text-fig. 2, H), and the peripheral edges of these plates often spread out over the internal surface of the cellwall to form extensive parietal films of chloroplast in the form of a delicate reticulum (Figs. 37, 45, 49, 56, Text-fig. 2, G). Very often practically the whole surface of the wall is thus mantled with a thin layer of photosynthetic matter, only small gaps being left. In $C$. ochthodes this parietal layer is often the seat of numerous tiny proteid granules, or naked pyrenoids (Figs. 37 and 49), and these have also been occasionally noticed in C. tetraophthalmum (Fig. 56). The ordinary large pyrenoids of the latter species show a particular tendency to multiply, and a group of two to four is commonly found embedded in the axis of one or more of its chloroplasts (Figs. 56 and 57).

\section{C. amoenum, C. subcucumis, C. reniforme, and C. biretum.}

In the chloroplasts of these species there are simple strands radiating from the axis rather than definite plates. The rather spherical mass of chloroplast containing the pyrenoid or group of pyrenoids sends out these projections towards the cell-wall in all directions, except towards the other chloroplast of the semi-cell (Figs. 62 and 70). One of these outgrowths usually connects up the axis of the chloroplast with the nucleus (Fig. 62). The chloroplast strands are very numerous, and may sometimes branch slightly (Figs. 64 and 66). On reaching the cell-wall they usually spread out to form irregularly shaped parietal masses lying against the cell-wall, forming a rough kind of network, which is, however, rather different from the more or less continuous parietal reticulum of $C$. ochthodes (Figs. 67 and 69).

The chloroplasts of the specimen of $C$. amoenum examined (Figs. 62 and 63 ) were not sufficiently massive to show the formation of a parietal network, but it is quite likely that under favourable conditions it is also developed in this species. 
In the case of $C$. biretum it was quite impossible to trace the parietal spreading of the ends of the chloroplast strands owing to the dense staining of the cell-wall itself, the chloroplasts being investigated entirely from sections (Figs. 64-6).

The pyrenoids of $C$. reniforme show a marked tendency to multiply, as many as three being commonly packed together in the axis of a single chloroplast (Fig. 69), whilst in several individuals of this species the small pyrenoids or proteid granules so common in $C$. ochthodes were also observed in the parietal parts of the chloroplast (Fig. 70).

\section{C. praemorsum.}

Examples of this species from Dartmoor were found to have chloroplasts almost exactly similar to those of $C$. formosulum, there being two axile chloroplasts in a semi-cell, each with a single pyrenoid. There was very little attempt at the formation of parietal films of chloroplast (Figs. 50 and $5 \mathrm{I})$.

Later, a collection of algae from a tank in the Botanical Department of the University of Bangor was provided by Dr. Acton, which contained, amongst others, two forms of Cosmarium, which, although differing slightly from each other, are both to be referred to the species $C$. praemorsum. The smaller of the two was typical $C$. praemorsum, and, like the other examples previously examined, contained two chloroplasts in each semi-cell. The other form was slightly larger, and differed from the first in its slightly projecting apices, whilst its chloroplasts were quite different (Text-fig. 2, C, $\mathrm{E}$, and $\mathrm{F}$ ). Here there was only one chloroplast in each semi-cell, consisting of an axis containing typically one pyrenoid, and several plates radiating towards the periphery (Text-fig. 2, C and D). The axis of the chloroplast was often shortened in the apical region of the semi-cell (Text-fig. 2, C).

A conspicuous character of this form was the unusual way in which the division of the central pyrenoid affects the chloroplast. Sometimes an individual was encountered having a compact group of two or three pyrenoids in the centre of the semi-cell, as one would naturally expect (Textfig. 2, E). But frequently there was a tendency for the two pyrenoids resulting from the division of the original one to separate from each other, and also for the chloroplast itself to constrict into two halves at the same time (Text-fig. 2, F). The union of the two parts of the chloroplast was always retained, however, even if only by means of a thin string-like strand connecting the two pyrenoids (Text-fig. 2, F, lower semi-cell). Sometimes even the starch-grains in the starch-sheaths of the pyrenoids were distorted by the pulling apart of the two halves of the chloroplast. Two separate chloroplasts were never observed, however, and so these variations in the form of the chloroplast are very difficult to explain. Because of the slightly different shape of the cell, and the fact that there is only one chloroplast in 
Carter.-Studies on the Chloroplasts of Desmids. III. 279

each semi-cell, this particular form may be a distinct variety of $C$.praemorsum. At any rate it is interesting to note that two different kinds of chloroplast structure may sometimes occur in the same species.

The remaining five species of Cosmarium examined were provided with parietal chloroplasts, which lie against or near the surface of the cell-wall. In $C$. Brebissonii the disposition of the chloroplasts is not always distinctly
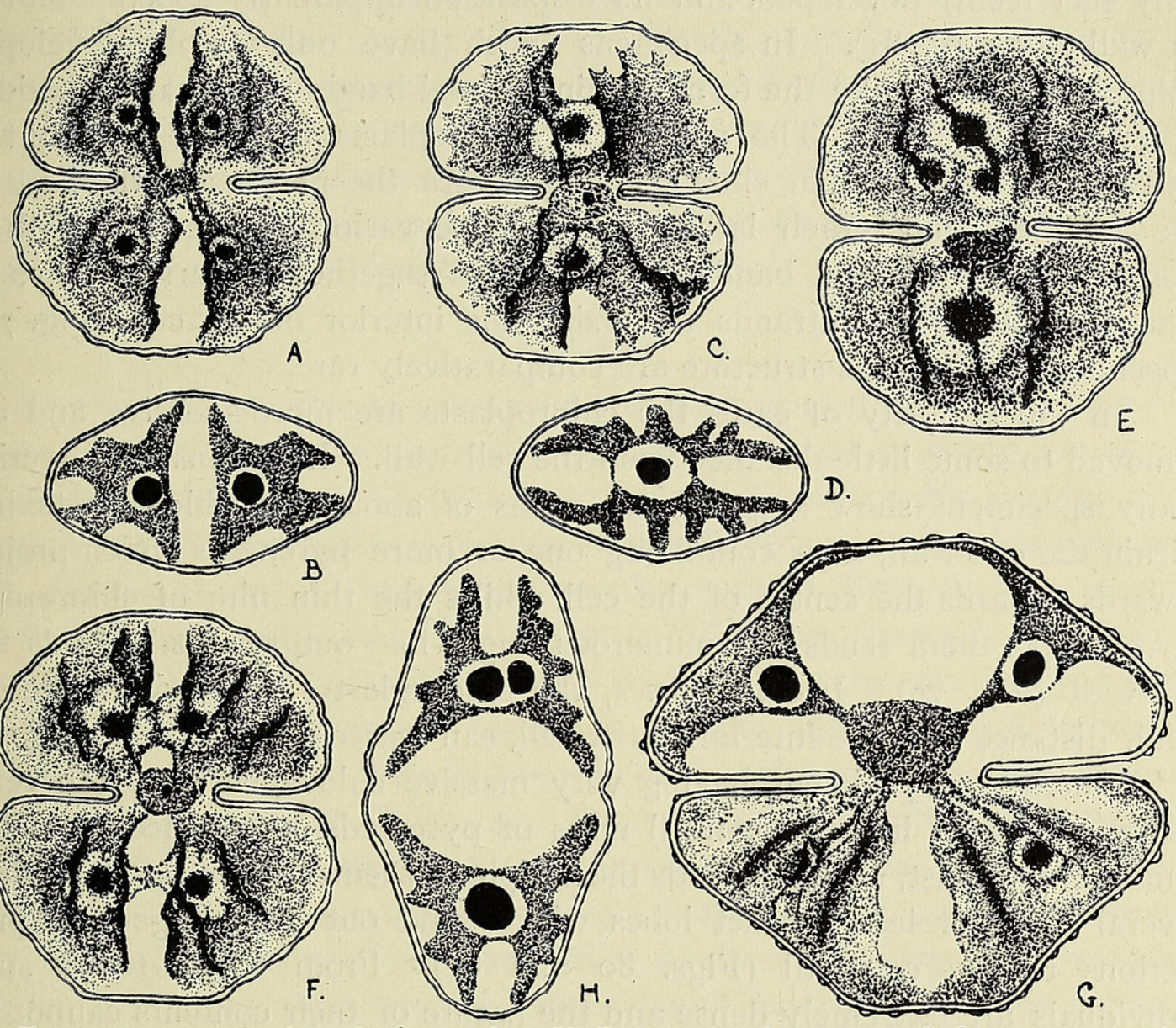

D.
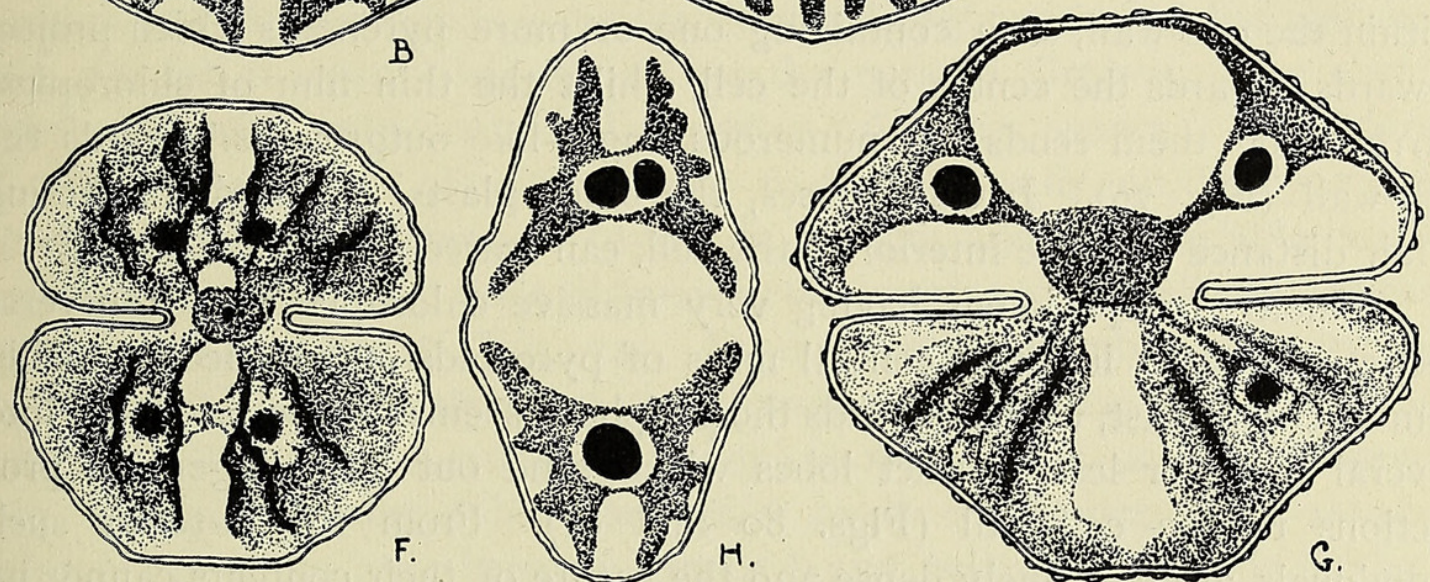

Text-Fig. 2. A and B, C. formosulum, Hoff : A, tront view ; B, optical transverse section. $\mathrm{C}-\mathrm{F}, \mathrm{C}$. praemorsum, Bréb.: C, front view; $\mathrm{D}$, end view; $\mathrm{E}$ and $\mathrm{F}$, showing irregularities in the number of pyrenoids. G and H, C. Turpinii, Bréb. : G, front view, upper semi-cell in optical section ; $\mathrm{H}$, optical transverse section. All $\times 8 \mathrm{I}$.

parietal owing to the irregular distending of the chloroplasts in all directions by the large and numerous pyrenoids (Figs. 75-8I ). The number of chloroplasts is often four, but they are subject to variation, especially in C. Brebissonii (Figs. 75-8I), whilst in size and number the pyrenoids also vary considerably, often becoming very numerous in the larger species (Figs. 82-5). This variation in number of the chloroplasts and pyrenoids is general with parietal chloroplasts.

Projections on the surface of the parietal expansions of chloroplast such as were described by Lütkemüller (1893) in C. tessellatum, \&c., have been observed in the chloroplasts of four of the five species examined having parietal chloroplasts. 


\section{Brebissonii.}

This species has most peculiar and variable chloroplasts which are quite different from those of any other species examined, and it is difficult to decide whether they should be considered axile or parietal. The general appearance varies considerably according as the chloroplast is massive or only very feebly developed, and its disposition apparently depends on this as well (Figs. 75-81). In specimens which have only feebly developed chloroplasts these take the form of thin parietal bands with small embedded pyrenoids (Fig. 78). The number of chloroplasts is about four, but is variable, and they are in close connexion with the nucleus at the base of the semi-cell, whilst their lateral margins are variously lobed or toothed. Sometimes the parietal bands are connected together in various ways by means of thread-like strands traversing the interior of the cell (Fig. 77). Specimens having this structure are comparatively rare.

In the majority of cases the chloroplasts are more massive and are removed to some little distance from the cell-wall. In a transverse section many specimens show a peripheral series of about five chloroplasts just within the cell-wall, each containing one or more pyrenoids which project inwards towards the centre of the cell, whilst the thin film of chloroplast surrounding them sends out numerous finger-like outgrowths towards the cell-wall (Fig. 79). In such cases, the chloroplasts, although projecting a fair distance into the interior of the cell, can scarcely be called axile.

Finally, in specimens having very massive chloroplasts, a transverse section shows an irregular central mass of pyrenoids surrounded by a thin film of chloroplast, which towards the periphery seems to associate itself into several more or less distinct lobes which send out long finger-like projections to the cell-wall (Figs. 80 and 8I). From the exterior such individuals are extremely dense and the nature of their contents cannot be elucidated. The pressure of one lobe of the chloroplast against its neighbour causes the formation of several longitudinal ridges, and this is all that can be distinguished in whole specimens.

Although the chloroplast of such specimens seems to be intact and solid in the middle of the semi-cell, towards the apex and base the lobes seem to become more distinct and free from each other, and here the chloroplast is more definitely parietal. Besides this, it often happens that in transverse section one lobe is seen to be quite free from the remaining solid mass of chloroplast and pyrenoids (Fig. 8I).

Taking into account all these points it seems wiser to consider that the chloroplast of C. Brebissonii consists of four to seven parietal parts. Each part begins as a thin strand near the nucleus and proceeds towards the apex of the semi-cell, spreading out laterally just beneath the cell-wall so as to screen, by the united efforts of all the chloroplasts, practically the whole 
surface (Fig. 75). Each chloroplast contains one to four pyrenoids, whilst its edges and external surface are usually covered with numerous tiny fingerlike outgrowths which stretch towards the cell-wall (Figs. 75 and 76). These outgrowths do not appear to have any definite relations with the granules on the external surface of the cell-wall, and sometimes become extraordinarily large, taking the form of short ridges running longitudinally. Sometimes a small chloroplast arises near the nucleus and stretches upwards, hidden in the interior of the cell, finally emerging near the apex of the semi-cell to form a parietal mass (Figs. 75 and 76). In cases where the pyrenoids become very numerous they cause extreme distortion of the chloroplasts, spreading farther and farther into the interior of the cell until the chloroplasts of opposite sides meet, and a practically solid mass of pyrenoids and chloroplasts is formed (Fig. 80 and $8 \mathrm{I}) .^{1}$

\section{C. cucumis.}

It was only possible to examine a few specimens of this species, and in all these there was a thin parietal layer of chloroplast covering the whole cell-wall in the form of a delicate reticulum. Occasionally a number of more or less distinct bands, running longitudinally, could be distinguished (Fig. 73), but it usually happened that the parietal film was quite evenly distributed, with only occasional irregular colourless spaces. The chloroplast was in all cases closely adherent to the cell-wall, and the pyrenoids, which were about fourteen to twenty in number and very variable in size, were suspended at some little distance in the interior of the cell by a delicate network of chloroplast (Fig. 74). In the limited number of specimens examined this delicate structure was general, and in no case were projections present on the external surface of the chloroplast. It is possible, however, that, had other material been available, specimens having more massive chloroplasts might have been encountered, and perhaps in such individuals the tiny outgrowths observed in the other species of the genus having parietal chloroplasts might be present.

\section{C. controversum.}

This species was originally described as having axile chloroplasts with two pyrenoids in each semi-cell. ${ }^{2}$ Its chloroplasts are parietal, however, four being the usual number (Fig. 86). Occasionally there are only two chloroplasts, one on each front face (Fig. 87), and possibly more than four may also sometimes occur. The chloroplast plates may be of some thickness and contain from one to five pyrenoids (Figs. 86-8). They are removed to

1 The pyrenoids also similarly distend the chloroplasts in certain species of Xanthidium having parietal chloroplasts, and here, too, the pyrenoids of opposite faces of the semi-cell are sometimes nearly incontact. See Carter, N. : Studies on the Chloroplasts of Desmids. I. Ann. Bot., vol. xxxiii, I9I9.

2 Vide West, W. and G. S. (1904-11), vol. iv, p. 9. 
some little distance from the cell-wall, and their edges and external surfaces are covered with outgrowths which project towards the periphery, each projection corresponding to one of the granules on the cell-wall, as described by Lütkemüller (1893) for C. tessellatum (Figs. 86-8).

\section{C. ovale and $C$. Askenasyi.}

In these two species there are usually four parietal chloroplasts in each semi-cell, two on each front face (Fig. 82.), although occasionally three may be present on one or other of the faces (Figs. 84 and 85 ). The main part of each chloroplast consists of a thin layer removed to some little distance from the cell-wall, and containing from six to twelve pyrenoids. In both species there are numerous tongue-like projections stretching from the external surfaces of the plates towards the periphery, those of $C$. Askenasyi being rather more delicate and relatively more numerous than those of C. ovale (Figs. $82-5$ ).

\section{Summary of the Special Characters of CosmariUm.}

Most of the species of Cosmarium examined have axile chloroplasts, although in a few the chloroplasts were parietal. In those species having axile chloroplasts there are either one or two chloroplasts in each semi-cell, and very often there is typically one pyrenoid in the axis of each chloroplast.

The statement that all species of the genus having axile chloroplasts possess either one or two pyrenoids in a semi-cell is untrue, although there are many species which have either one or two points of pyrenoid formation. As in other genera of the Desmidiaceae, the actual number of pyrenoids present depends on the individual itself, and at any time a group of pyrenoids may be formed where originally there was only one.

Many of the smaller species have a single chloroplast in each semi-cell consisting of a central axis, containing typically one pyrenoid, from which radiate either four more or less forked plates or a number of simple ridges or string-like outgrowths.

In $C$. diplosporum there is a rough kind of parietal network arising from the lateral expansion of the ends of the chloroplast rays extending from the central axis.

The plates arising from the central axis containing the central pyrenoid or group of pyrenoids are in C.pseudopyramidatum very complicated in form and irregular in arrangement.

C. pyramidatum is similar to the previous species in the form and arrangement of its plates, but differs in its more delicate axis and in the arrangement of its pyrenoids, which, unlike those of $C$. pseudopyramidatum, rarely occupy the centre of the chloroplast. 
C. achondroides differs from the first type in that the lateral lobes of its chloroplast are provided with pyrenoids as well as its central axis.

In C. pseudoconnatum the chloroplast is axile with four wedge-shaped masses radiating towards the periphery, each mass possessing typically one pyrenoid.

C. ornatum and C. Ralfsii differ from all other species examined having axile chloroplasts in their scattered pyrenoids. There are rarely more than three in the former species, but in the larger one they are much more numerous. The chloroplast of $C$. Ralfsii shows striking resemblances to those found in certain thick-celled species of Micrasterias.

Many species of Cosmarium have two axile chloroplasts in each semicell, there being one point of pyrenoid formation in each chloroplast. The axis which contains the pyrenoid or group of pyrenoids is surrounded by a number of radiating plates, or more numerous string-like projections, whose peripheral edges in many cases spread out over the internal surface of the cell-wall, either in irregular parietal masses, or as a more or less continuous reticulated film.

Two forms of $C$. praemorsum were examined, containing one and two chloroplasts in a semi-cell respectively.

C. Brebissonii was found to have most peculiar and variable chloroplasts, which are sometimes parietal, but in other individuals penetrate into all parts of the cell.

In a few species the chloroplasts were found to be entirely parietal, with scattered pyrenoids. In such species the number of chloroplasts and pyrenoids present is variable.

In conclusion, I wish to express my gratitude to the Birmingham Natural History Society, and also to the Royal Society, for grants to help in the cost of reproducing the plates illustrating this work. I have also to acknowledge the invaluable help which I received during this investigation from the late Professor G. S. West, who not only identified all the species examined, but also provided some of the material.

\section{BIBLIOGRAPHY.}

DE BARY, A. (1858) : Untersuchungen ïber die Familie der Conjugaten. Leipzig, I 858.

Delponte, J. B. (1873) : Specimen Desmidiacearum subalpinum. Augustae Taurinorum, 1873. Memor. d. R. Accad. d. Scienze di Torino, ser. 2, xxviii.

Ducellier, F. (1917): Notes sur le pyrénoïde dans le genre Cosmarium Corda. Bulletin de la Société Botanique de Genève, $2^{\mathrm{me}}$ série, vol. ix, 1917.

GAY, F. (1884): Essai d'une Monographie locale des Conjuguées. Montpellier, I 884.

KLEBS, G. (1879): Über die Formen einiger Gattungen der Desmidiaceen Ostpreussens. Schriften d. Physik. Oek. Gesellsch, zu Königsberg, I 879 . 


\title{
284 Carter. - Studies on the Chloroplasts of Desmids. III.
}

LAGerheim, G. (1888): Über Desmidiaceen aus Bengalen nebst Bemerkungen über die geographische Verbreitung der Desmidiaceen in Asien. Bihang till K. Svenska Vet.-akad. Handlingar, Band I3, No. 9, I888.

Lundell, P. M. (1871): De Desmidiaceis quae in Suecia inventae sunt observationes criticae Nova Acta Reg. Soc. Scient. Upsala, ser. 3, xiii, 187 I.

LütKemülleR, J. (1893): Beobachtungen über die Chlorophyllkörper einiger Desmidiaceen. Oesterr. botan. Zeitschrift, I 893, Nr. I u. 2. (1910) : Zur Kenntnis der Desmidiaceen Böhmens. Verhandl. der k k. Zool.Botan. Ges., lx, I910.

NëGELI, C. (1849): Gattungen einzelliger Algen. Zürich, I849.

West, G. S. (1909): The Algae of the Yan Yean Reservoir, Victoria : a Biological and Oecological Study. Journ. Linn Soc, vol. xxxix, 1909.

Wes', W. and G. S. (1904-11): Monograph of the British Desmidiaceae. Roy. Soc., vol, i, 1904; ii, I905; iii, 1908; iv, I9II.

\section{DESCRIPTION OF PLATES X-XIII.}

\author{
Illustrating Dr. Nellie Carter's paper on the Chloroplasts of Desmids.
}

During the prolonged processes of preparation the specific characters of Desmids are often obliterated, but all the species examined were identified, either in the living or carefully fixed condition, by the late Professor G. S. West.

\section{PLATE $\mathrm{X} . \quad($ All $\times 8 \mathrm{I}$ o. $)$}

Figs. I-5. Cosmarium subtumidum, Nordst. Figs. I and 2, front view; Figs. 3-5, various transverse sections.

Figs. 6 and 7 . C. crenatum, Ralfs. Fig. 6, front view; Fig. 7 , optical transverse section.

Figs. 8 and 9. C. contractum, Kirchn. Fig. 8, front view; Fig. 9, optical transverse section.

Figs. Io and I I. C. caelatum, Ralfs. Fig. IO, front view ; Fig. I I, optical transverse section. section.

Figs. I2 and I3. C. elegantissimum, Lund. Fig. I2, front view; Fig. I3, optical transverse

Figs. I4 and 1 5. C. cucurbita, Bréb. Fig. I4, front view ; Fig. I 5, transverse section.

Figs. 16-20. C. punctulatum, Bréb. Figs. 16 and 17 , front view; Figs. 18-20, transverse sections.

Fig. 21. C. diplosporum, (Lund.) Liitkem., front view, lower semi-cell in optical section.

Figs. 22 and 23. C. pseudopyramidatum, Lund. Fig. 22, front view ; Fig. 23, optical transverse section.

Figs. 24-7. C. pyramidatum, Bréb. Fig. 24, front view; Fig. 25, side view; Fig. 26, optical longitudinal section of a large specimen containing numerous pyrenoids; Fig. 27 , optical transverse section of a similar individual.

Figs. 28-30. C. speciosum, Lund. Fig. 28, front view ; Fig. 29, side view ; Fig. 30, optical transverse section. section.

Figs. 3I and 32. C. depressum, Lund. Fig. 3I, front view; Fig. 32, optical transverse

Figs. 33 and 34. C. ornatum, Ralfs. Fig. 33, front view ; Fig. 34, optical transverse section.

Figs. 35 and 36. C. pseudoconnatum, Nordst. Fig. 35, front view; Fig. 36, transverse section.

\section{PLATE XI. (All $\times 810$.}

Figs. 37-49, C. ochthodes, Nordst. Fig. 37, front view ; Figs. 38-4I, serial transverse sections from the apex of the semi-cell to the sinus; Figs. $42-4$, serial longitudinal sections, parallel to the lateral faces of the cell, through one half of the semi-cell and one chloroplast only ; Figs. 45-9, 


\section{Carter.-Studies on the Chloroplasts of Desmids. III. 285}

serial longitudinal sections parallel to the front faces of the semi-cell $(s$, starch grains of the sheaths of the pyrenoids). section.

Figs. 50 and 5I. C. praemorsum, Bréb. Fig. 50, front view; Fig. 5I, optical transverse

Figs. $5^{2}$ and 53. C. margaritiferum, Menegh. Fig. 52, front view; Fig. 53, transverse section.

Figs. 54 and 55. C. binum, Nordst. Fig. 54, front view ; Fig. 55, optical transverse section.

Figs. $5^{6}$ and 57 . C. tetraophthalmum, Bréb. Fig. $5^{6}$, front view; Fig. 57 , optical transverse section.

\section{PLATE XII.}

Figs. 58-6r. C. Ralfsii, Bréb. $\times$ 510. Figs. $5^{8-60}$, various individuals in front view; Fig. 6I, transverse section. section

Figs. 62 and 63 C. amoenum, Bréb. $\times 810$. Fig. 62, front view; Fig. 63, optical transverse

Figs. 64-6. C. biretum, Bréb. $\times 8$ ro. Fig. 64 , longitudinal section parallel to front faces of the cell; Fig. 65 , transverse section; Fig. 66, longitudinal section parallel to the lateral faces of the cell (contents of lower semi-cell not shown).

Figs. 67 and 68. C. subcucumis, Schmidle. $\times 8$ 10. Fig. 67 , front view (right-hand chloroplast of lower semi-cell in optical section); Fig. 68, optical transverse section.

Figs. 69 and 70. C. reniforme, (Ralfs.) Arch. $\times 8$ Iо. Fig. 69 , front view (right-hand chloroplast of upper semi-cell in optical section); Fig. 7o, optical transverse section.

Figs. $7 \mathrm{I}$ and 72. C. pachydermum, Lund, $\times 8 \mathrm{IO}$. Fig. $7 \mathrm{I}$, front view; Fig. 72, optical transverse section.

Figs. 73 and 74. C. cucumis, Corda. $\times 8$ ro. Fig. 73, front view; Fig. 74, optical longitudinal section.

\section{PLATE XIII.}

Figs. 75-81. C. Brebissonii, Menegh. $\quad \times 8$ Iо. Fig. 75 , front view; Fig. 76 , longitudinal section; Figs. 77 and 78 , optical transverse sections of the two semi-cells of an individual having very scanty chloroplasts ; Figs. 79-81, transverse sections of various individuals. section.

Figs. 82 and 83 . C. ovale, Ralfs. $\times 5$ 10. Fig. 82 , front view; Fig. 83 , optical longitudinal

Figs. 84 and 85. C. Askenasyi, Schmidle. $\times 5$ 10. Fig. 84 , front view; Fig. 85 , optical transverse section.

Figs. 86-8. C. controversum, West. $\times 8$ 10. Fig. 86 , front view ; Fig. 87 , optical transverse section ; Fig. 88, optical longitudinal section. 

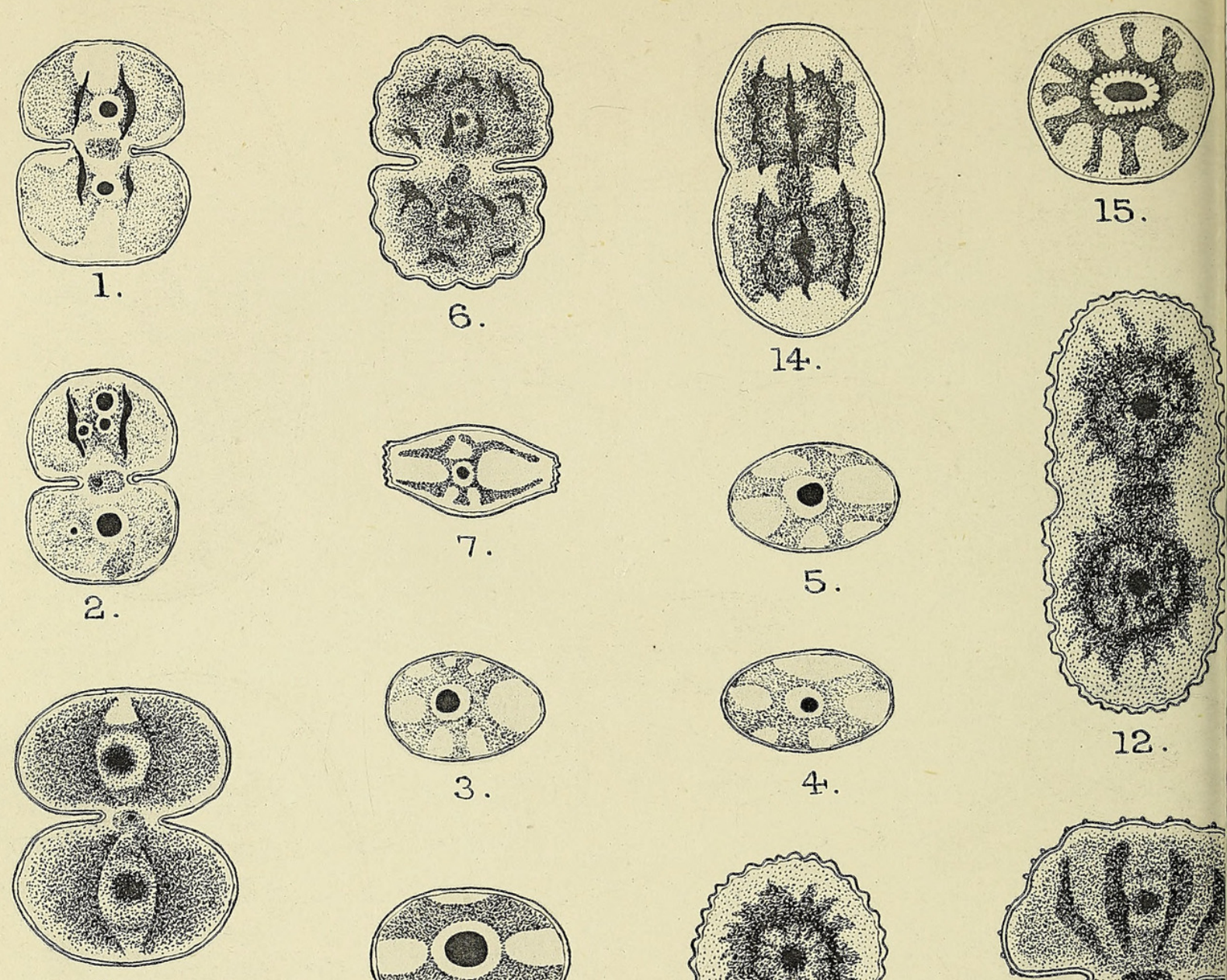

8.
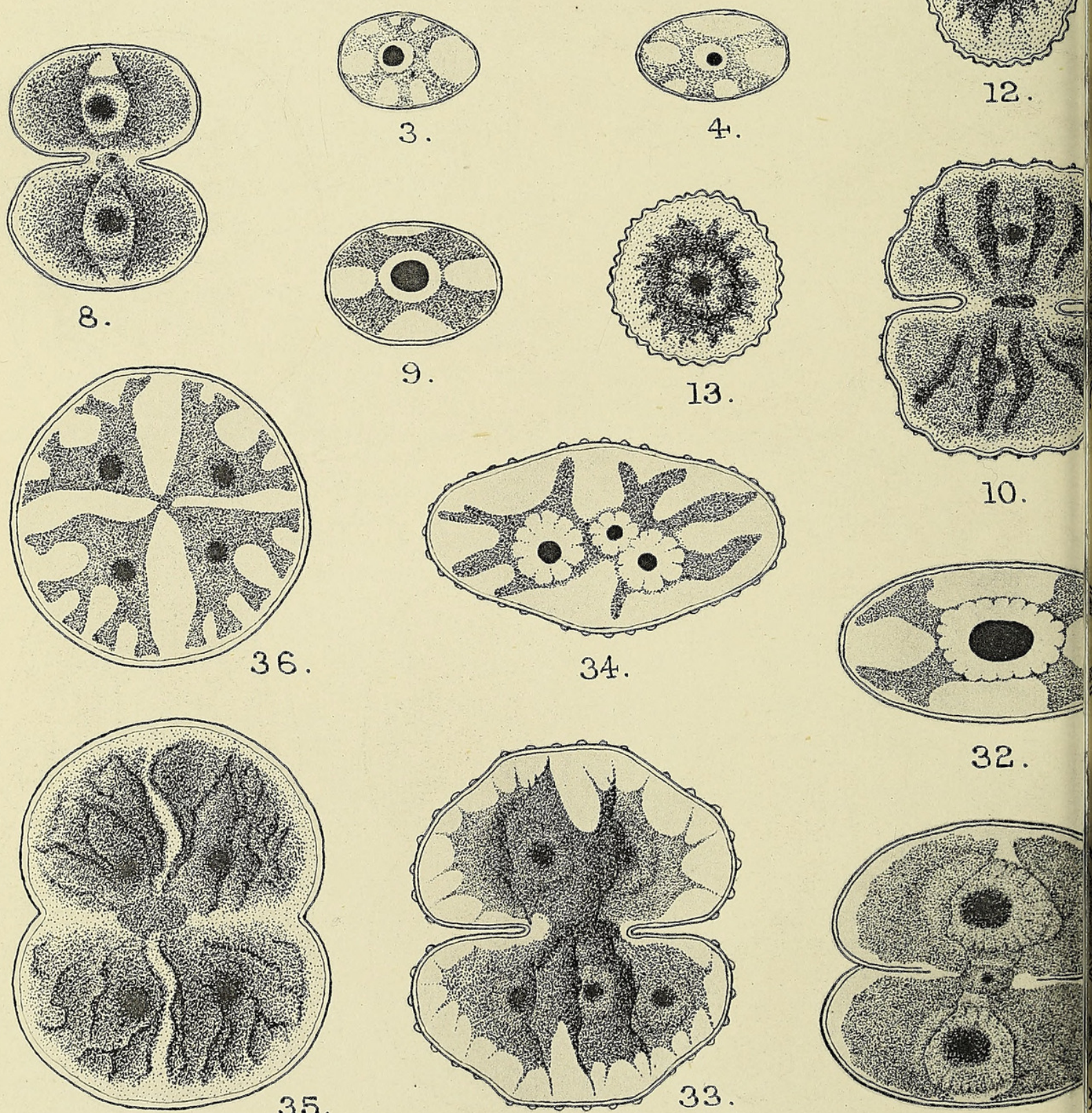

13.
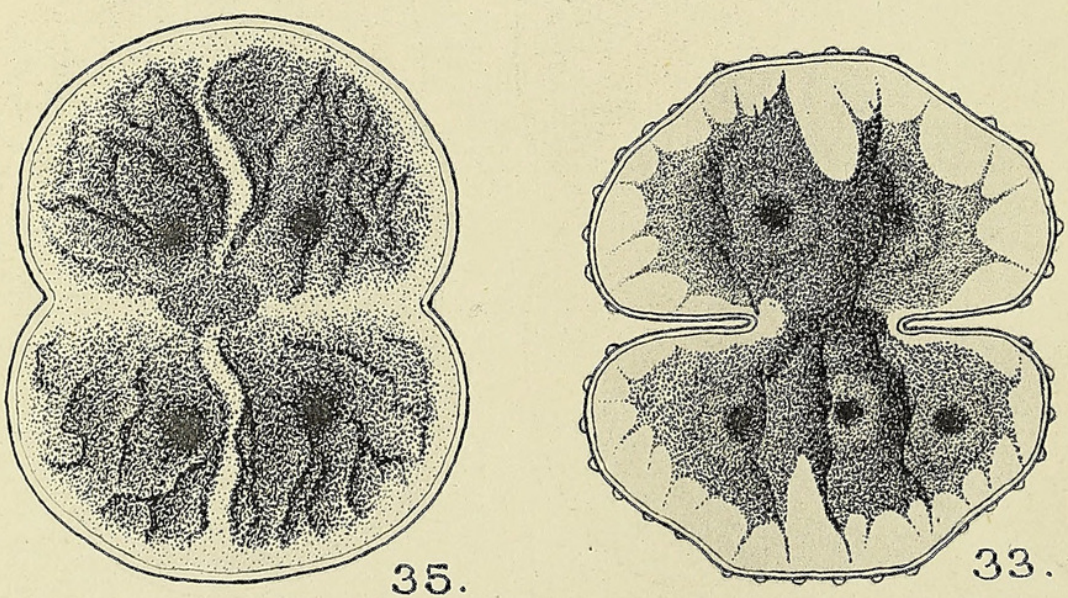

N. CARTER- COSMARIUM. 
Annals of Potany.
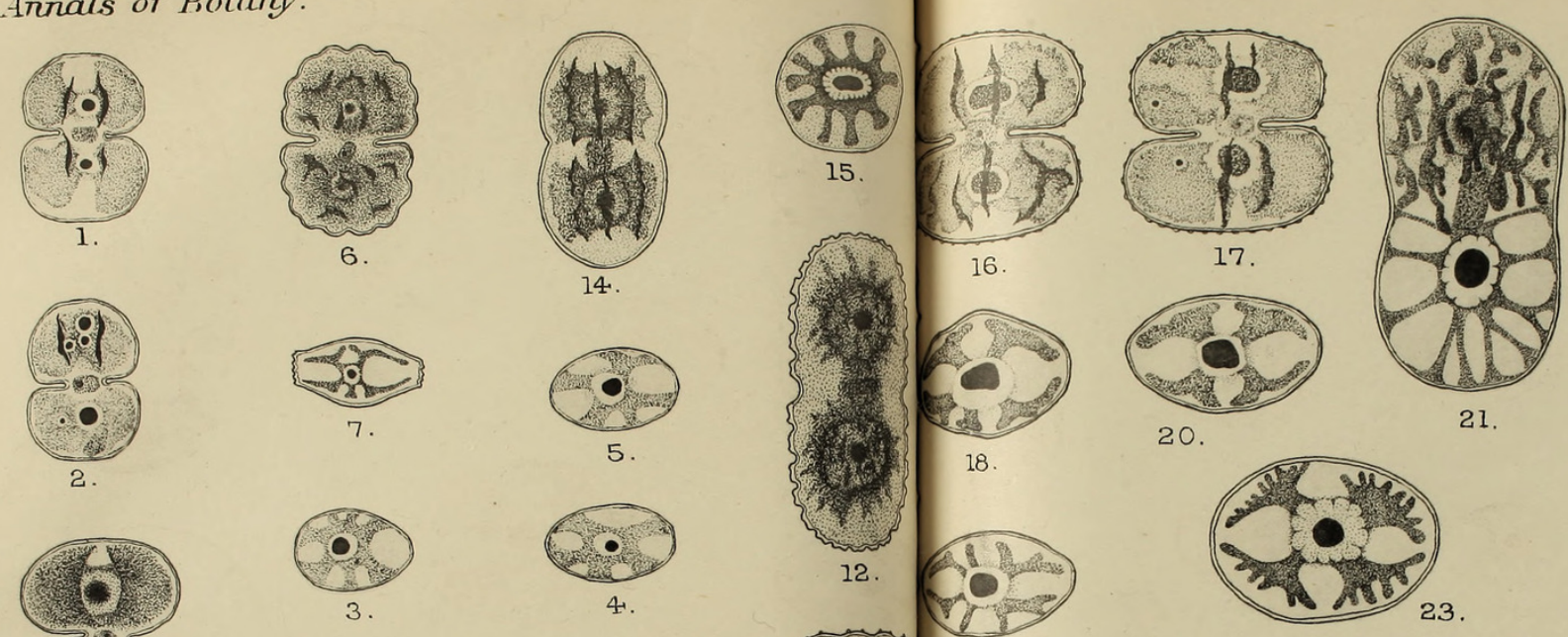

Vol. XXXIV. PL.X

619
0
0
0
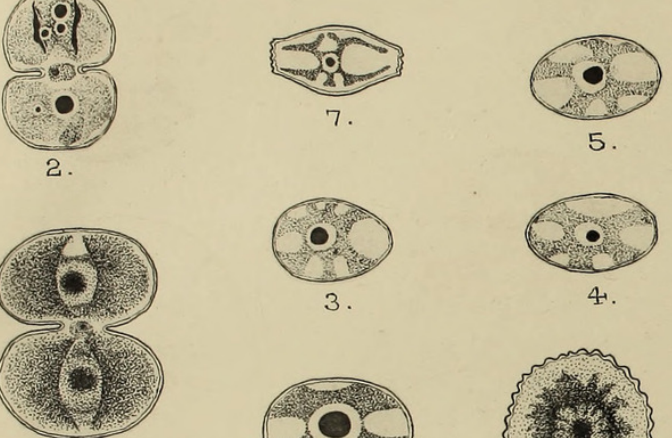

8.
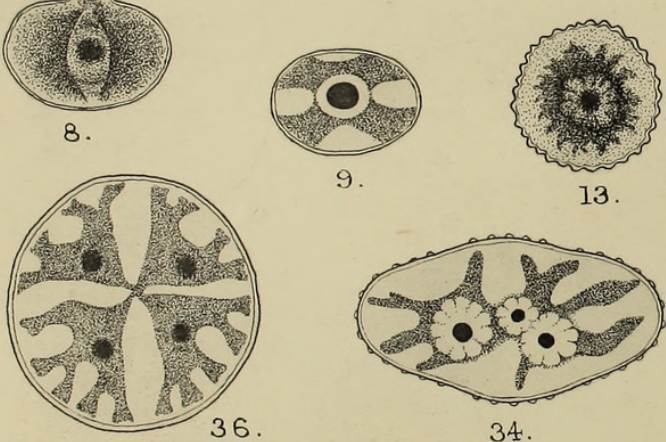

13
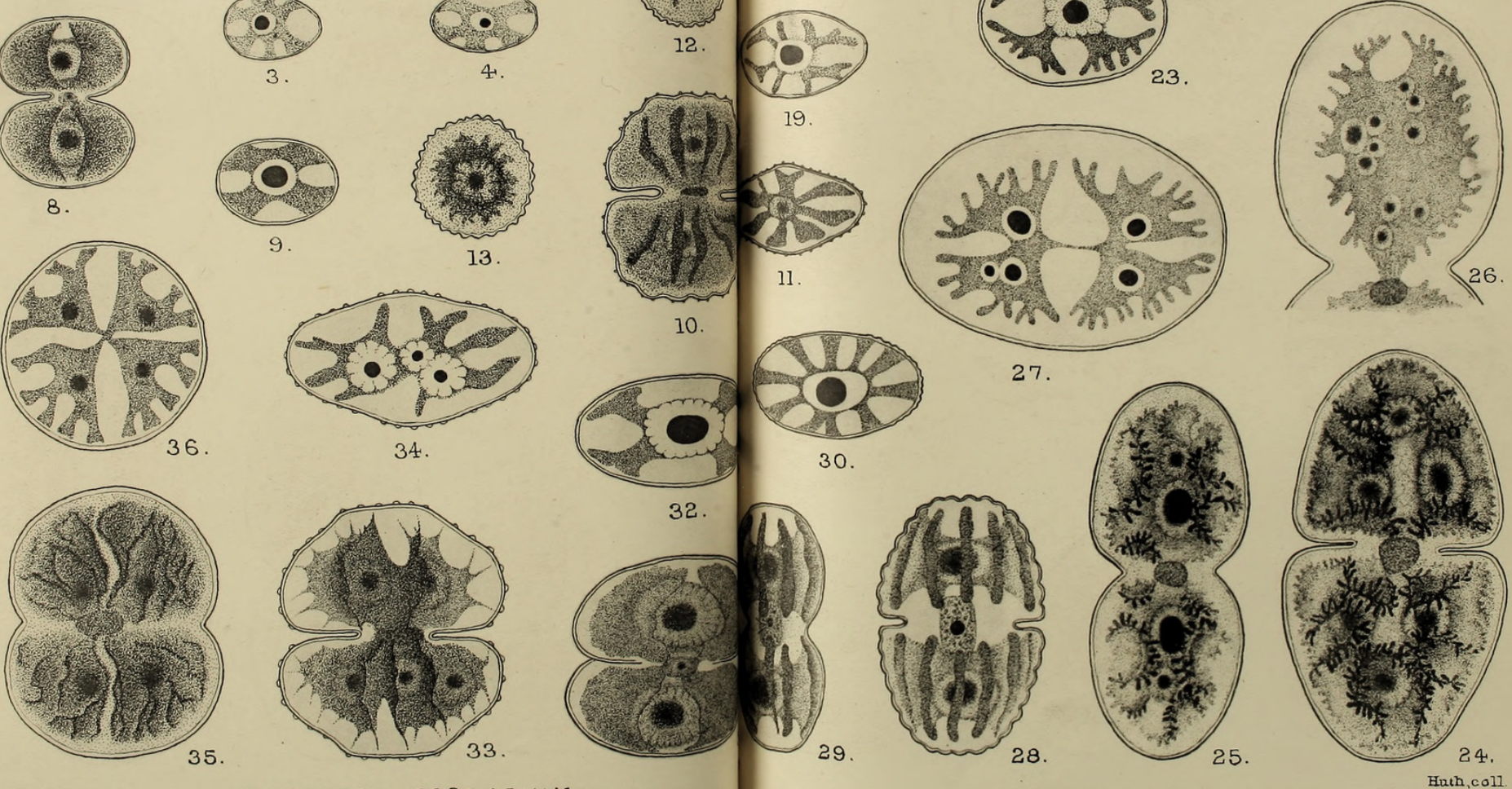

N. CARTER- COSMARIUM. 
Annals of Botany.
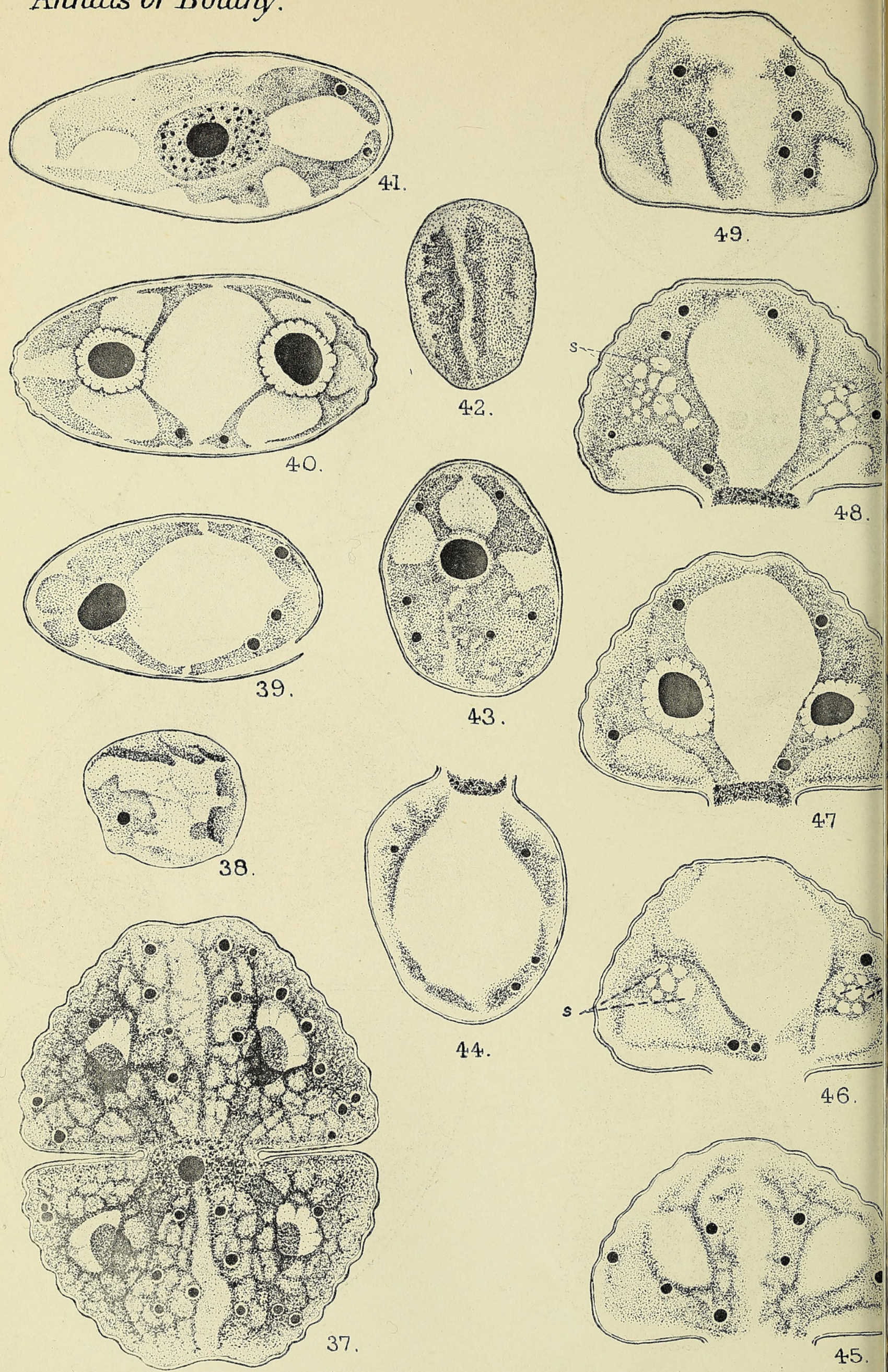

N. CARTER COSMARIUM.

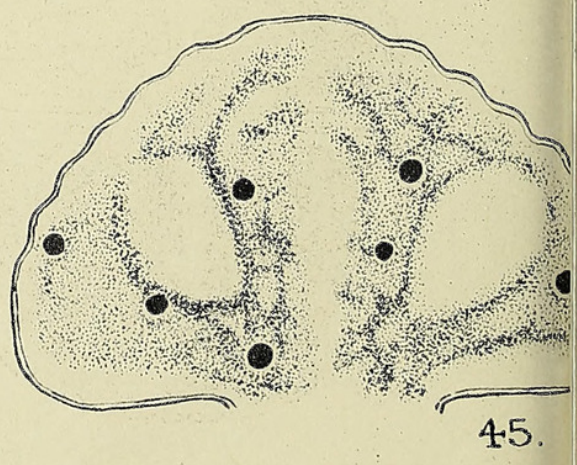


Vol. XXXIV.PI.XI.
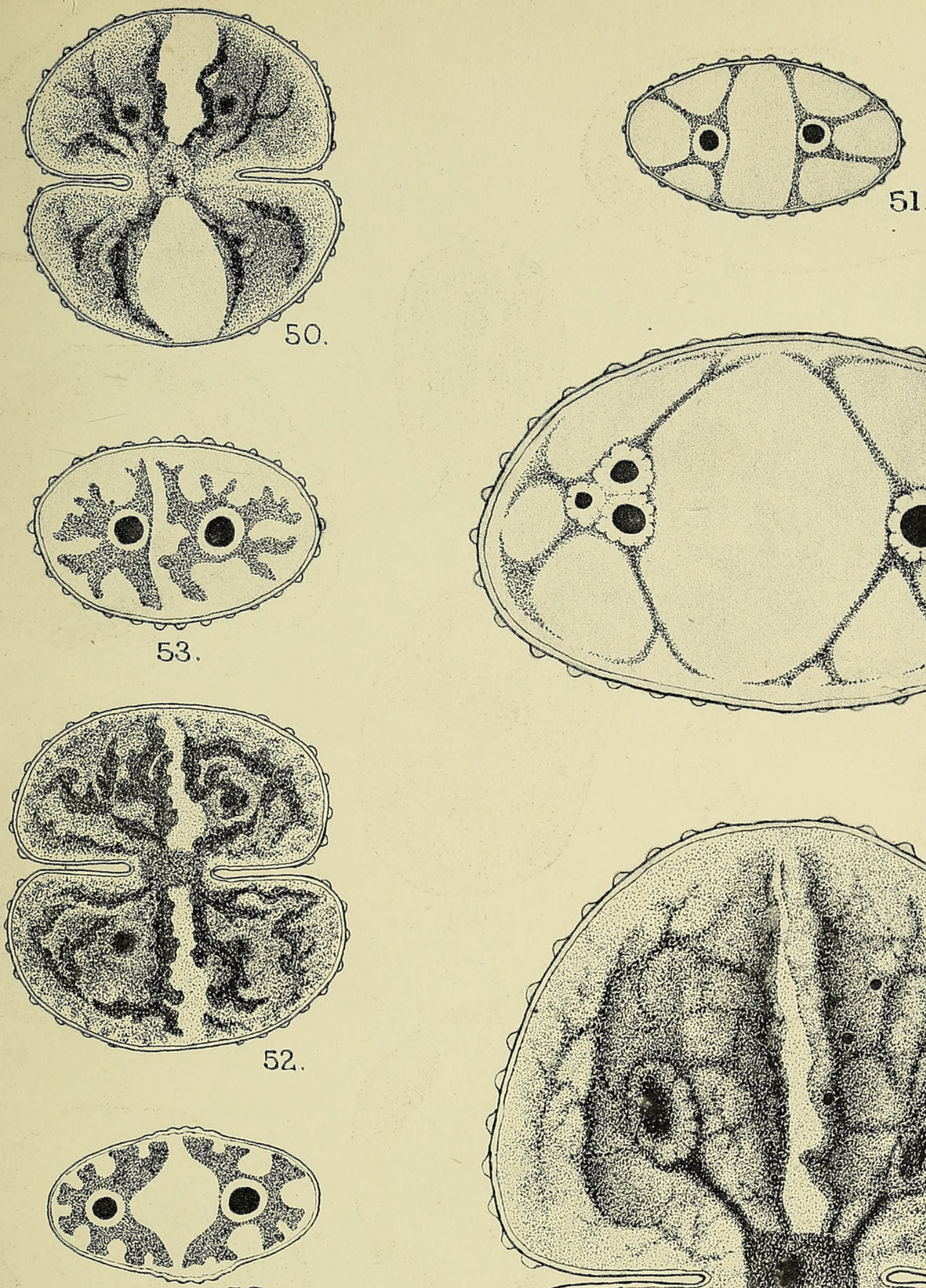

55.
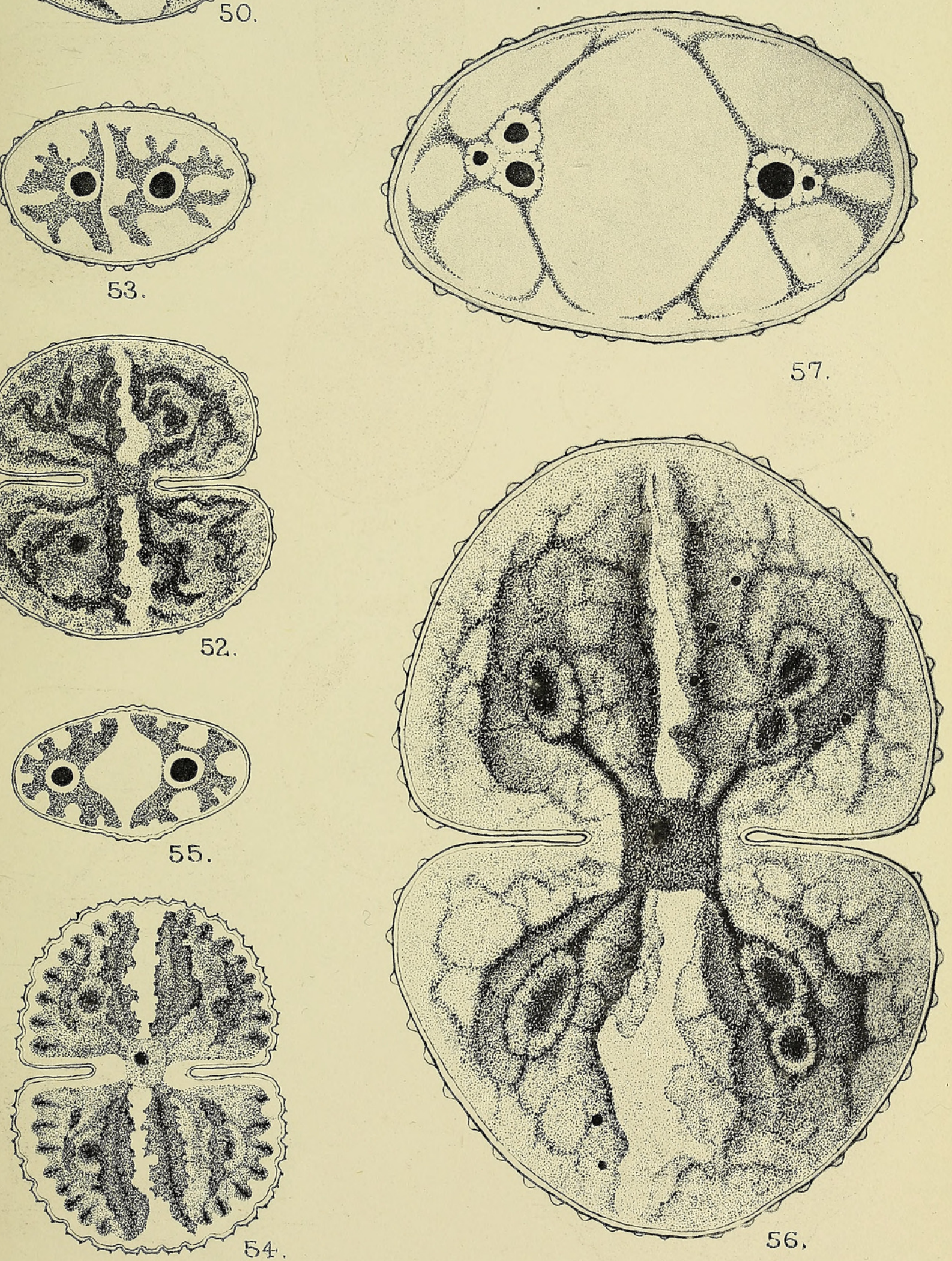

Fruth, coll. 


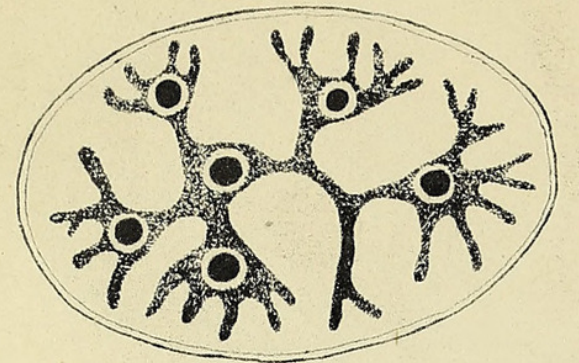

61.
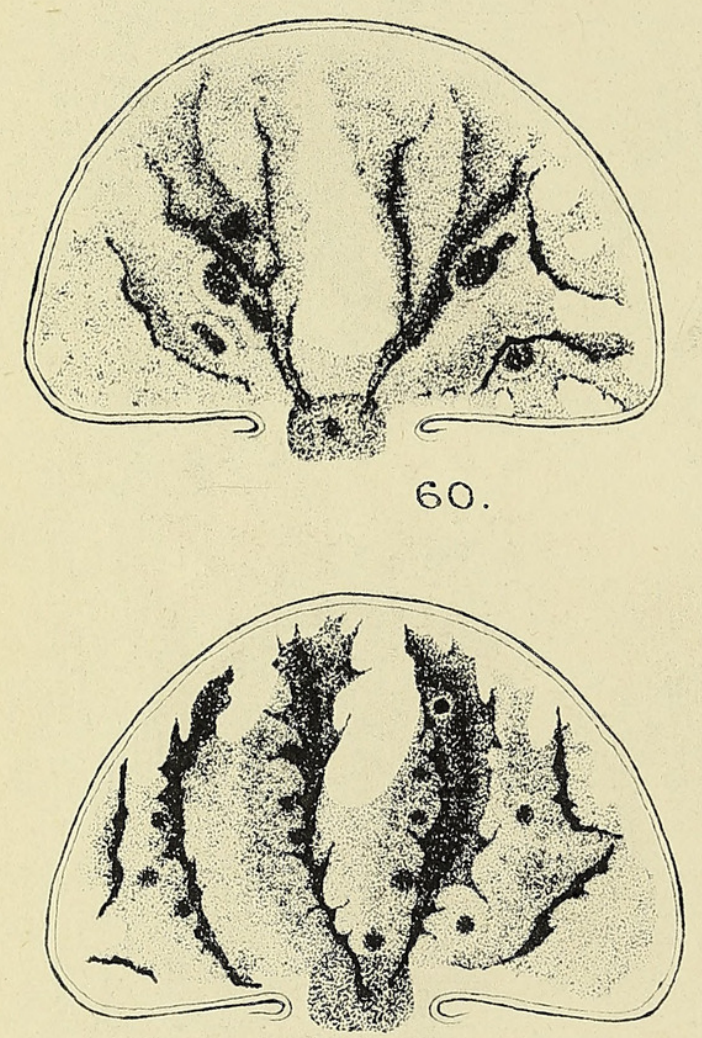

59.

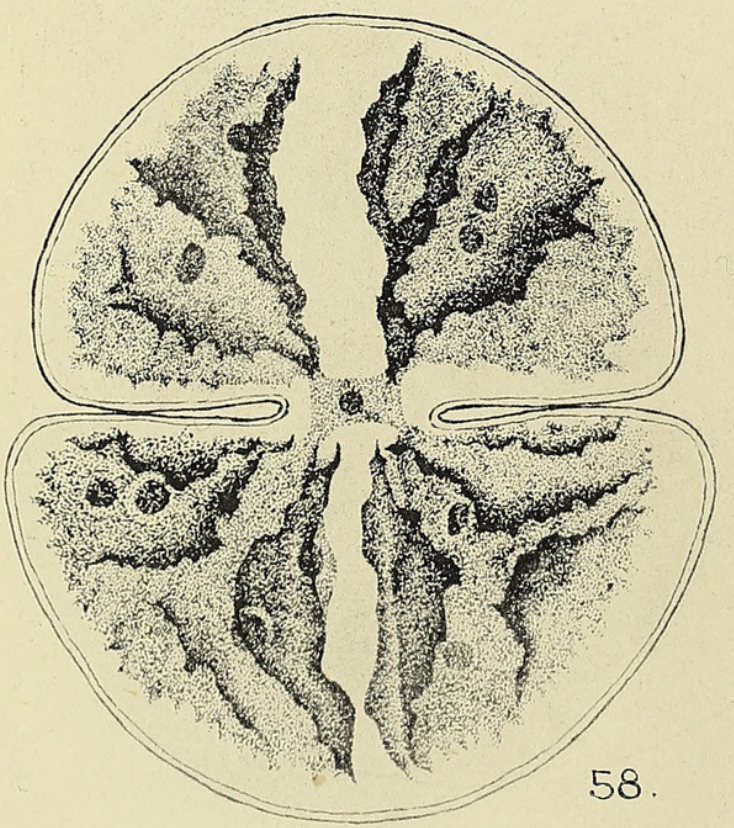

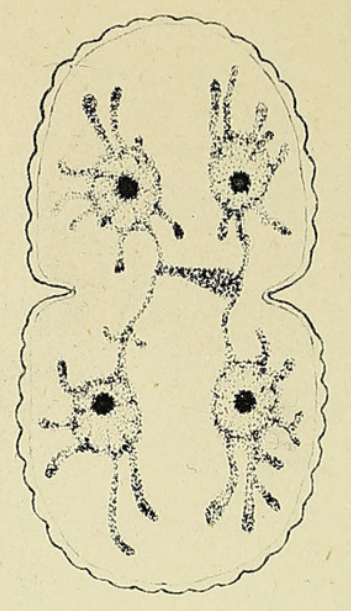
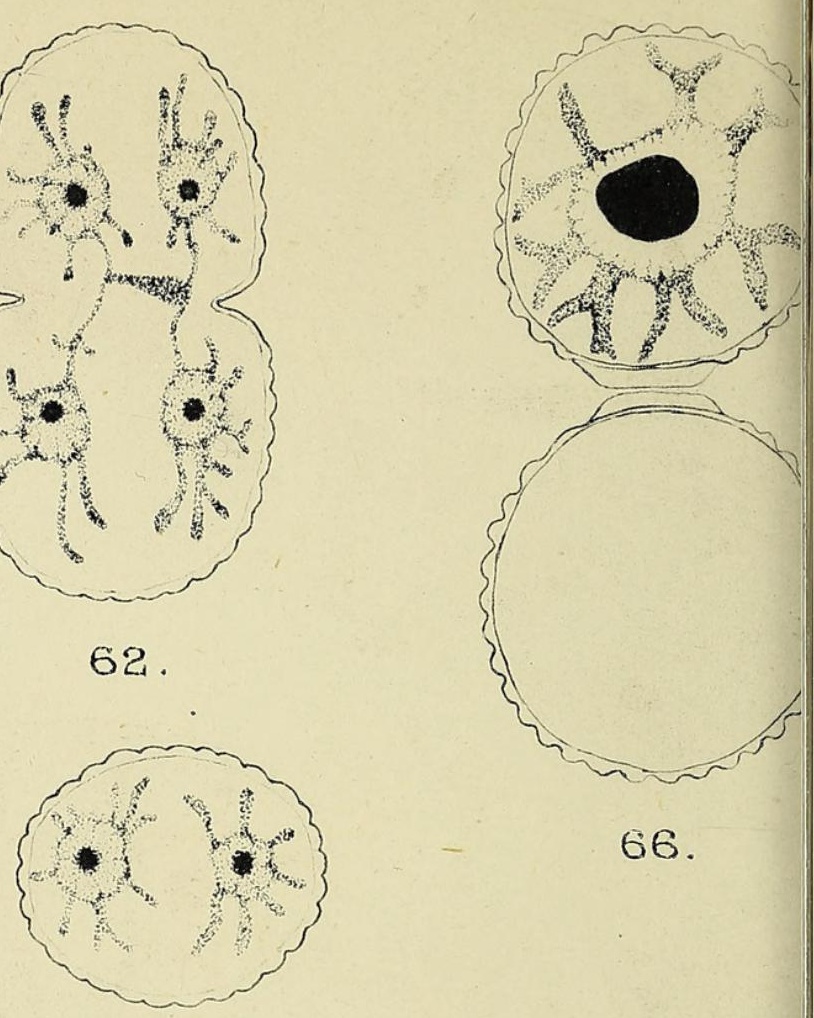

66.
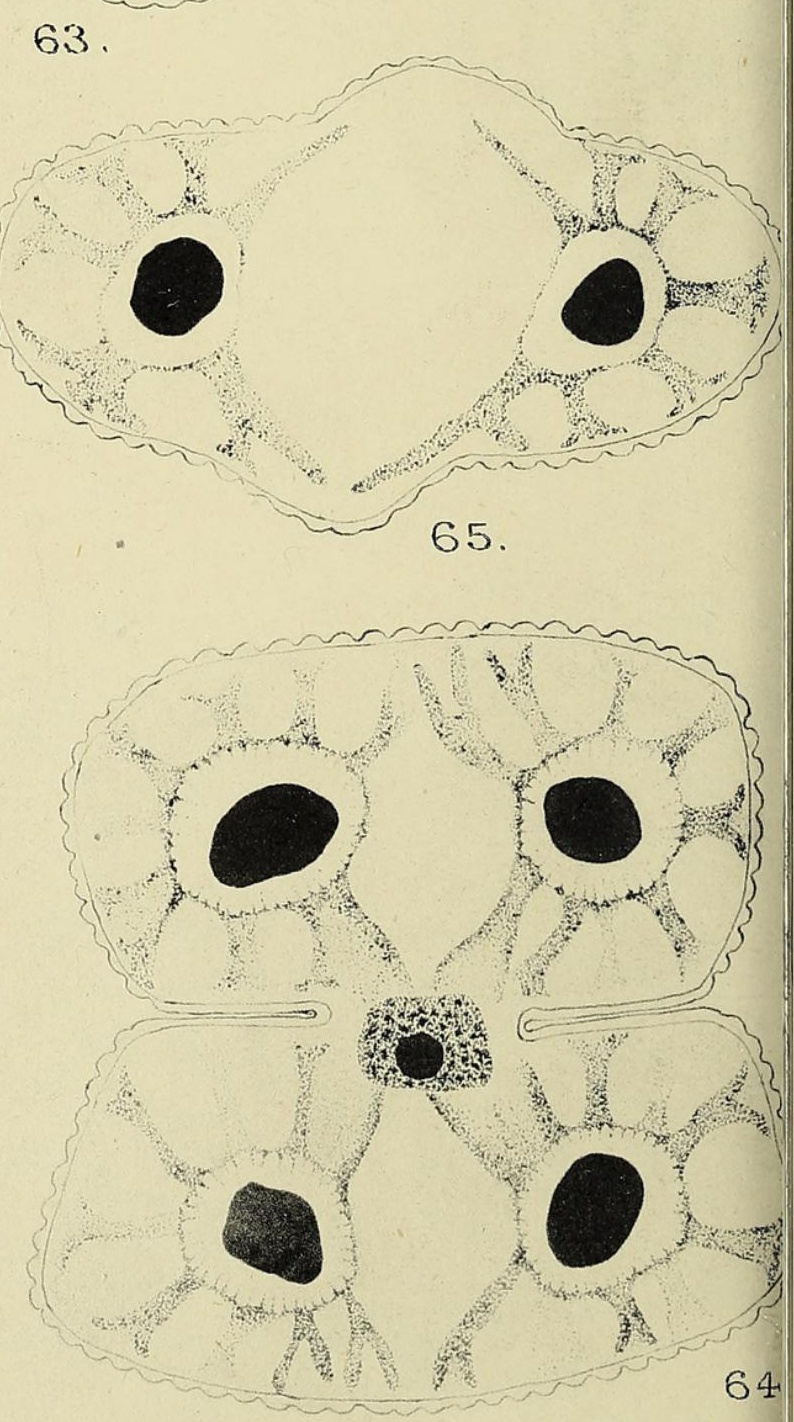

N. CARTER - COSMARIUM. 


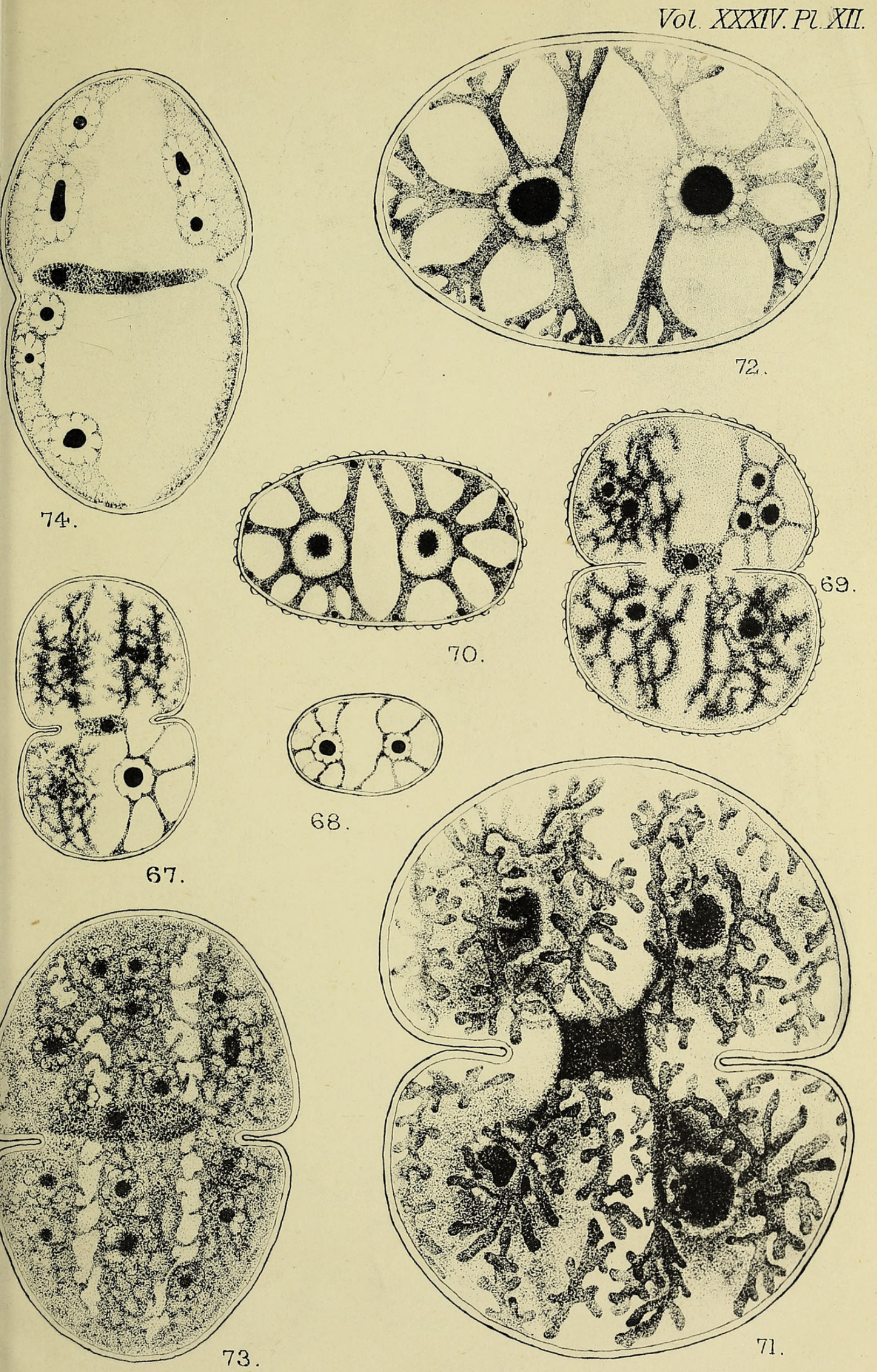

Huth, coll 


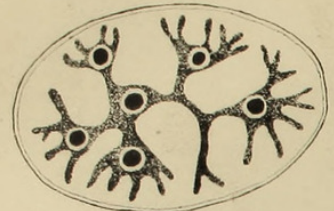

61.
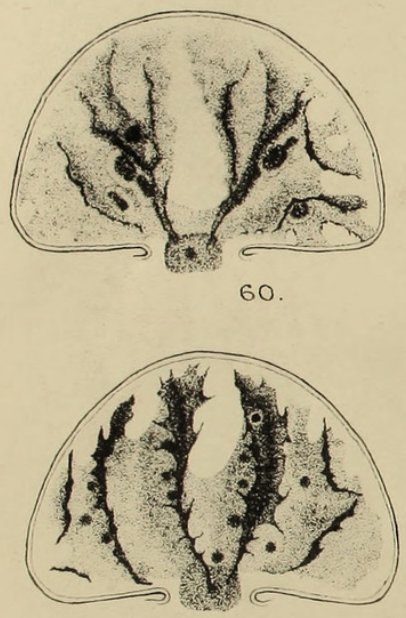

59.

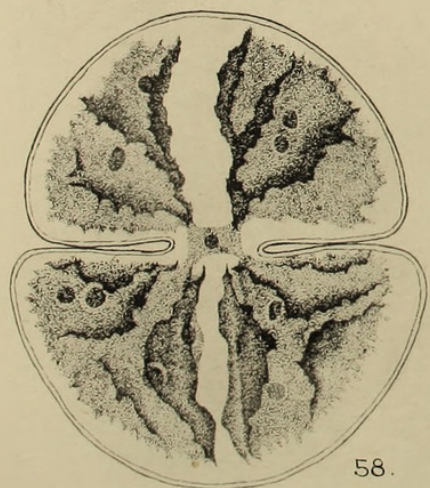

N. CARTER - COSMARIUM.

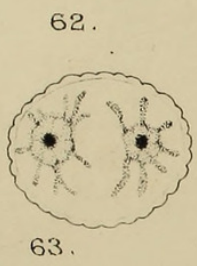

Vol. XXXIV. Pl. XII.
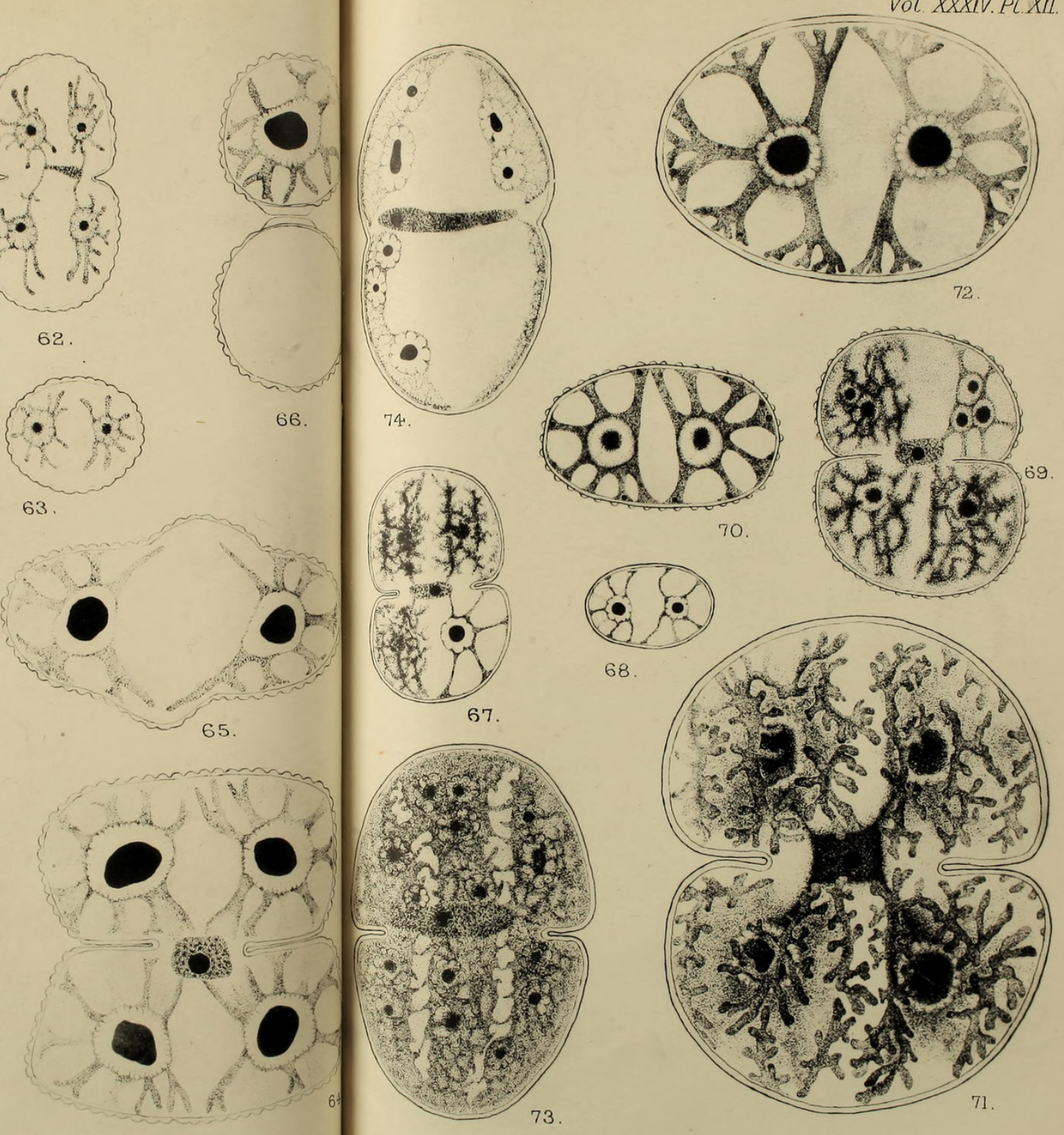

Futh, coll. 
Annals of Botany
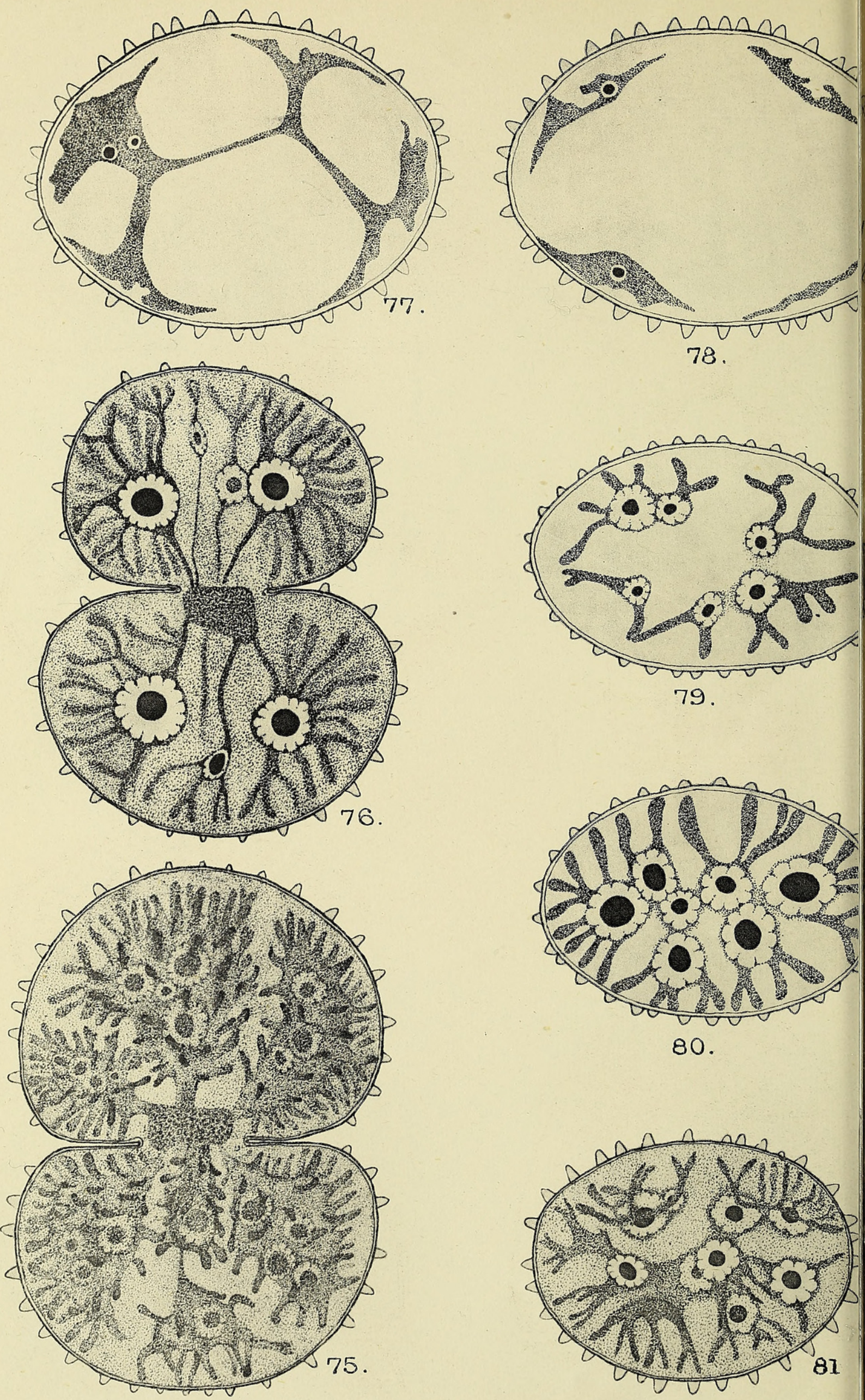

N. CARTER COSMARIUM. 
Annals of Botany
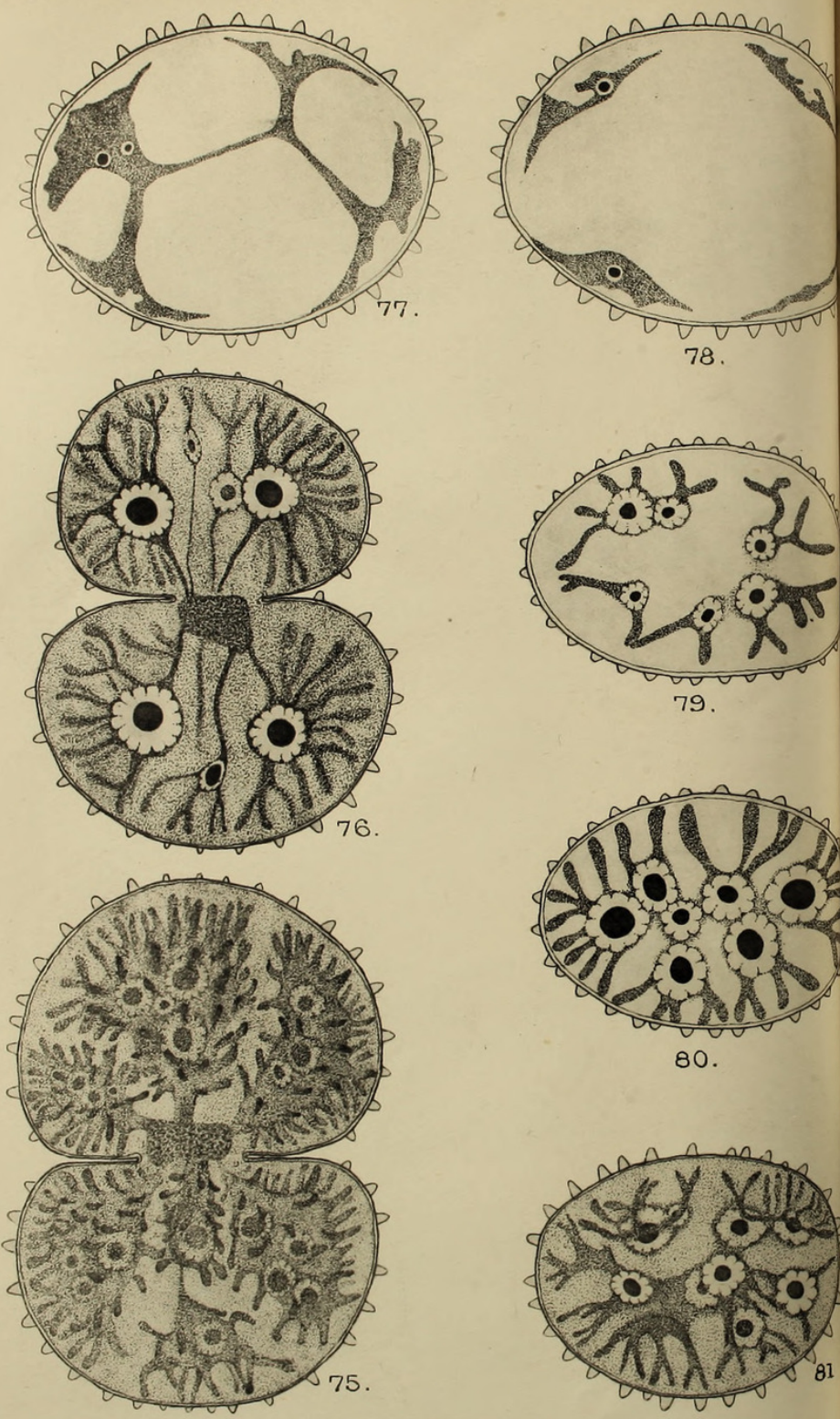
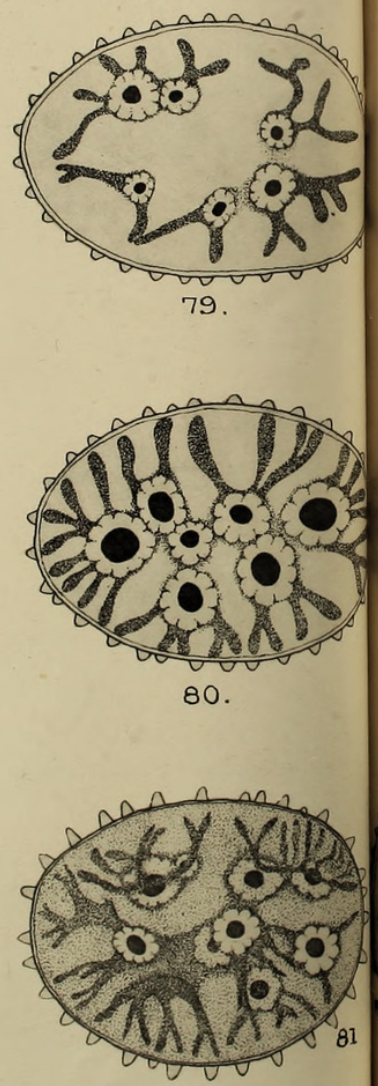
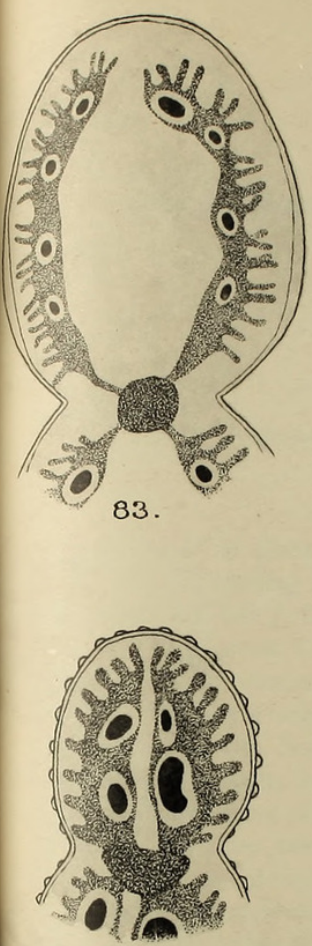

88 .

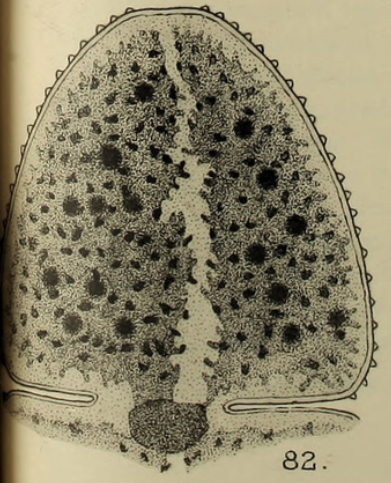

Vol. XXXXIV, PZ. XIII.
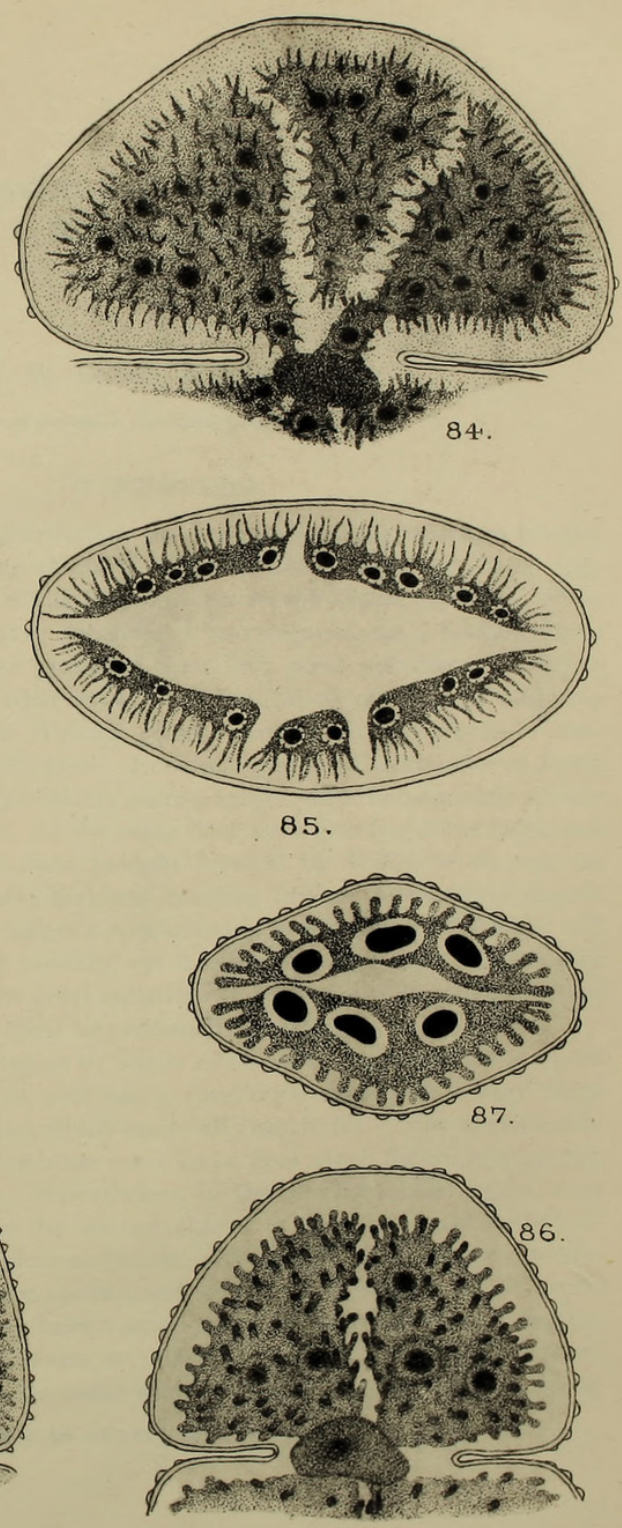

Huth, coll. 


\section{$2 \mathrm{BHL}$ Biodiversity Heritage Library}

Carter, Nellie. 1920. "Studies on the chloroplasts of Desmids. III. X. The Chloroplasts of Cosmarium." Annals of botany 34, 265-285.

https://doi.org/10.1093/aob/os-34.2.265.

View This Item Online: https://www.biodiversitylibrary.org/item/236972

DOI: https://doi.org/10.1093/aob/os-34.2.265

Permalink: https://www.biodiversitylibrary.org/partpdf/320287

\section{Holding Institution}

Smithsonian Libraries

\section{Sponsored by}

Biodiversity Heritage Library

\section{Copyright \& Reuse}

Copyright Status: Not in copyright. The BHL knows of no copyright restrictions on this item.

This document was created from content at the Biodiversity Heritage Library, the world's largest open access digital library for biodiversity literature and archives. Visit BHL at https://www.biodiversitylibrary.org. 